\title{
Synthesis, in silico studies and cytotoxicity evaluation of novel 1,3,4-oxadiazole derivatives designed as potential mPGES-1 inhibitors
}

\author{
Gizem ERENSOY 1 (D), Kai DING 2,3 (D), Chang-Guo ZHAN 2,3 (D), Ammar ELMEZAYEN 4 (D), \\ Kemal YELEKÇi் 4 (D), Merve DURACIK 5 (D), Özlem BİNGÖL ÖZAKPINAR 5 (D), \\ İlkay KÜÇÜKGÜZEL ${ }^{1}$ * (D)
}

1 Department of Pharmaceutical Chemistry, Faculty of Pharmacy, Marmara University, Haydarpaşa 34668 İstanbul, Turkey.

2 Department of Pharmaceutical Sciences, College of Pharmacy, University of Kentucky, 789 South Limestone Street, Lexington, KY 40536, United States.

3 Center for Pharmaceutical Research and Innovation, College of Pharmacy, University of Kentucky, 789 South Limestone Street, Lexington, KY 40536, United States.

4 Department of Bioinformatics and Genetics, Faculty of Engineering and Natural Sciences, Kadir Has University, İstanbul, Turkey.

5 Department of Biochemistry, Faculty of Pharmacy, Marmara University, Haydarpaşa 34668 İstanbul, Turkey.

* Corresponding Author. E-mail: ikucukguzel@marmara.edu.tr (İ.K.); Tel. +90-216-414 2963.

Received: 18 May 2020 / Revised: 24 June 2020 / Accepted: 25 June 2020

\begin{abstract}
A series of new 1,3,4-oxadizole derivatives containing thioether group, has been synthesized to investigate their mPGES-1 inhibitory activities. The synthesized compounds were also evaluated for their anticancer and COX-1/2 inhibitory activities. All compounds were checked for their purity using TLC and HPLC analyses. The melting points, elemental analysis, FT-IR, $1 \mathrm{H}-/{ }^{13} \mathrm{C}-\mathrm{NMR}$ and LR-MS data were utilized for structural characterization. The most potent derivative was 2-[5-\{[2-methyl-5-(propan-2-yl)phenoxy]methyl\}-1,3,4-oxadiazol-2-yl)sulphanyl]-1(phenyl)ethan-1-one 3a, which showed inhibitory activity against mPGES-1 with an $\mathrm{IC}_{50}$ of $4.95 \mu \mathrm{M}$. Docking studies with mPGES-1 and COX-1/2 enzymes revealed their affinity and potential binding mechanism for the tested compounds.
\end{abstract}

KEYWORDS: 1,3,4-Oxadiazoles; thioethers; mPGES-1 inhibition; COX-1/2 inhibition; anticancer activity; molecular docking; ADME prediction.

\section{INTRODUCTION}

Cyclooxygenase (COX) enzymes are critical macromolecular targets for the management of inflammation, pain and fever. Two major isoforms, COX-1 and COX-2 are structurally similar enzymes, but their regulations are different. While COX-1 is continuously released from many cells under normal physiological conditions, COX-2 is induced by cytokines, growth factors and bacterial endotoxins in case of inflammatory stimuli. These enzymes are also responsible for increased amount of prostaglandins in case of inflammation [1-3]. Prostaglandin $\mathrm{E}_{2}\left(\mathrm{PGE}_{2}\right)$ is the most abundant one among all of them [4] and isomerization of $\mathrm{PGE}_{2}$ is catalyzed with microsomal prostaglandin synthases (mPGES). $\mathrm{PGE}_{2}$ is responsible for vascular inflammation and synthesized via mPGES enzymes [5]. Because of side effects of long-term use of COX-1 and COX-2 inhibitors $[6,7]$ three different microsomal prostaglandin synthases: mPGES-1, mPGES-2 and cPGES (cytosolic) has become newly important target for inflammatory stimuli. Among them mPGES-1 is the most related one to inflammation pathway [8] and it is known that COX-2 and mPGES-1 are induced in response to inflammation [5]. According to earlier reports, mPGES-1 enzyme has also been associated with different diseases such as Alzheimer's, atherosclerosis, rheumatoid arthritis, neuroblastoma and different types of cancer [9].

1,3,4-Oxadiazole is a significant scaffold possessing different biological effects such as antiinflammatory [10], antitubercular [11], anticancer [12-15]. Additionally, 1,3,4-oxadiazole heterocycle is bioisosteres of ester and amide functional groups [14]. Thioether derivatives have also been shown to have many different biological activities such as anticancer [14, 16-19], antimicrobial [20], anti-inflammatory [21, 22], antiviral properties [23].

How to cite this article: Erensoy G, Ding K, Zhan CG, Elmezayen A, Yelekçi K, Duracık M, Bingöl-Özakpınar Ö, Küçükgüzel I. Synthesis, in silico studies and cytotoxicity evaluation of novel 1,3,4-oxadiazole derivatives designed as potential mPGES-1 inhibitors. J Res Pharm. 2020; $24(4)$ : 436-451. 
Carvacrol (5-isoporopyl-2-methylphenol) which is starting compound of our study, is a derivative of monoterpenic phenol available from the Labiatae family. Antifungal [24], antimicrobial [25], antioxidant [26] activities have been reported for carvacrol as well as anticancer [27-29], anti-inflammatory activity [30-32].

Figure 1 shows promising recent mPGES-1 inhibitors under investigation. An indole-carboxylic acid derivative, 1-[(4-chlorophenyl)methyl]-3-[(tert-butylsulfanyl]-5-(propan-2-yl)-1H-indole-2-yl-2,2-dimethyl propanoic acid MK886, inhibited mPGES-1 in vitro in nanomolar range [33].

Various chemical classes of compounds like phenanthrene imidazoles (MF-63) [34], 2,4-biarylimidazol derivatives [35], trisubstituted urea derivates [36], imidazoquinoline derivatives [37-39], sulfonamide derivatives [40] has been identified as mPGES-1 inhibitors. Natural products obtained from plants also showed anti-inflammatory effect by inhibiting mPGES-1 and/or COX enzymes [9]. The differences between human and murine mPGES-1 enzyme [41] and problems such as strong plasma protein binding and high lipophilicity [8,42], none of these compounds have been identified as therapeutic agent. The compound LY3023703 has been reported as first one, entered the clinical trial [43]. Recently, Glenmark Pharmaceuticals developed dihydropyrido[4,3- $d$ ]pyrimidine a compound, which has entered phase I, clinical trial named GRC27864 (Clinical Trials Identifier: NCT02179645) [44]. Compound 4b, a 5-arylmethylenebarbituric acid derivative was developed by Chang Guo Zhan's lab as an inhibitor of mPGES-1 enzyme [45].

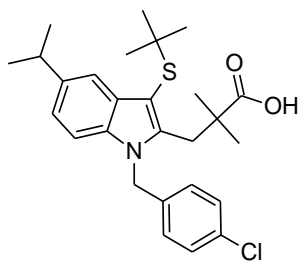

MK-886<smiles>Cc1cccc(C#N)c1-c1nc2c3ccccc3c3cc(Cl)ccc3c2[nH]1</smiles>

MF-63

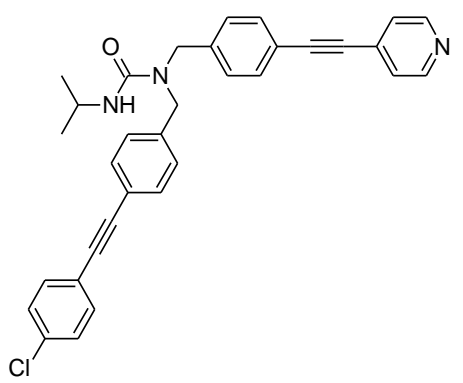<smiles></smiles><smiles>CC(C)C(=O)NCc1ccc(Cl)c(-c2nc3cc(-c4ccc(C(F)(F)F)cc4)ncc3c(=O)[nH]2)c1</smiles><smiles>O=S(=O)(Nc1cccc(O)c1O)c1ccc(-c2ccccc2)cc1</smiles>

GRC 27864<smiles>O=C1NC(=O)C(=Cc2ccc(OCCCCC3CCCCC3)c(Cl)c2)C(=O)N1</smiles>

$4 \mathrm{~b}$

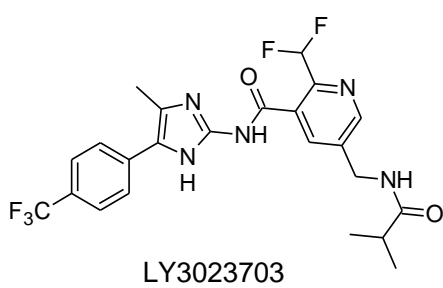

Figure 1. Previously reported mPGES-1 inhibitors.

It is known that the specific inhibition of mPGES-1 reduces the amount of $\mathrm{PGE}_{2}$ induced by inflammation but does not change the amount of COX-dependent prostanoids. From this point of view, mPGES-1 inhibitors are not expected to cause side effects as in the case of other non-steroidal antiinflammatory drugs and COX inhibitors [46]. Also, in a recent study, the amount of $\mathrm{PGE}_{2}$ decreased with mPGES-1 inhibition, whereas $\mathrm{PGF}_{2 \alpha}$ and $\mathrm{TxB}_{2}$ increased. It was revealed that COX-2 inhibition decreases the synthesis of other prostanoids. This demonstrates the selectivity of mPGES-1 rather than COX-2 [47]. Therefore, mPGES-1 has become a very important target for novel anti-inflammatory drug discovery studies.

The compound with new thioether scaffold like our newly synthesized compounds inhibits mPGES-1 enzyme at the concentration of $9.3 \mathrm{nM}$ in cell free assay and $0.7 \mu \mathrm{M}$ in human whole blood assay [21]. Although it is known that 1,3,4-oxadiazole derivates can show anti-inflammatory potency (10), to our knowledge only one compound containing 1,3,4-oxadiazole scaffold showed inhibitory effect against mPGES-1 at $0.42 \mu \mathrm{M}$ [48]. Herein this study we report the identification of a new type of inhibitors combining both 1,3,4-oxadiazole and thioether groups through both computational and experimental studies (Figure 2). 


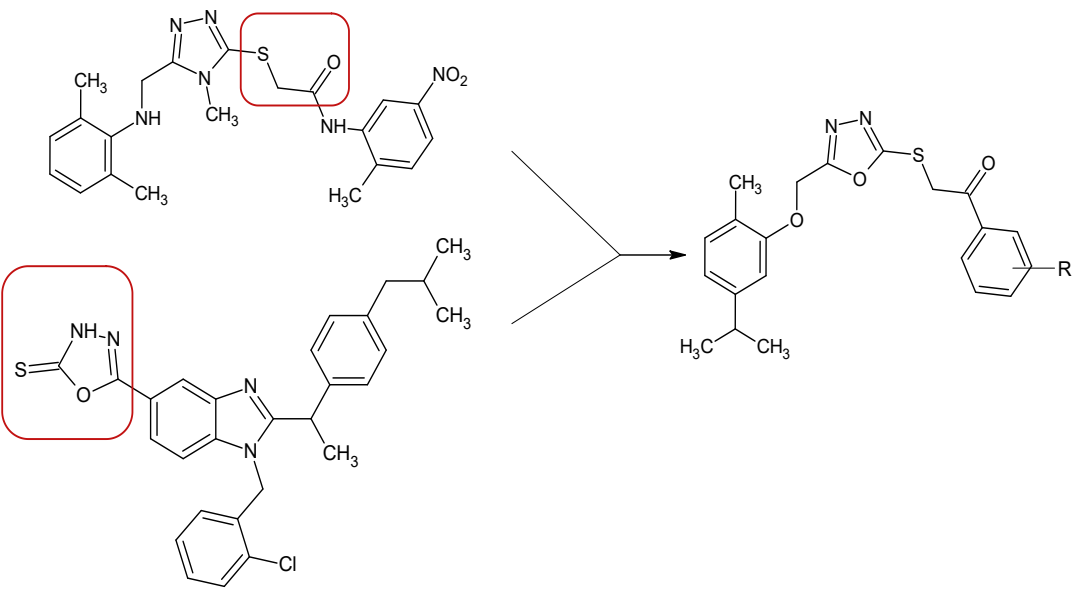

Figure 2. Hybridization of 1,3,4-oxadiazole and thioether groups.

\section{RESULTS and DISCUSSION}

\subsection{Chemistry}

Ethyl 2-[2-methyl-5-(propan-2-yl)phenoxy]acetate 1 was prepared by the reaction of carvacrol with ethyl bromoacetate in dry acetone [16,49]. Heating compound 1 with hydrazine hydrate in ethanol gave 2-[2methyl-5-(propane-2-yl)phenoxy]acetohydrazide 2. 5- $2[2-$ Methyl-5-(propan-2-yl)phenoxy]methyl $\}-1,3,4-$ oxadiazole-2-(3H)-thione 3 was obtained by the reaction of compound 2 with $\mathrm{KOH}$ and $\mathrm{CS}_{2}$ in ethanol. As the final step, 2-[5-\{[2-methyl-5-(propan-2-yl)phenoxy]methyl\}-1,3,4-oxadiazol-2-yl)sulphanyl]-1-(substituted phenyl) ethanone derivatives (3a-f) were carried out by the reaction of appropriate $\alpha$-bromoacetophenone derivatives with compound 3 in the presence of triethylamine (TEA) in acetonitrile [22] (Figure 3).

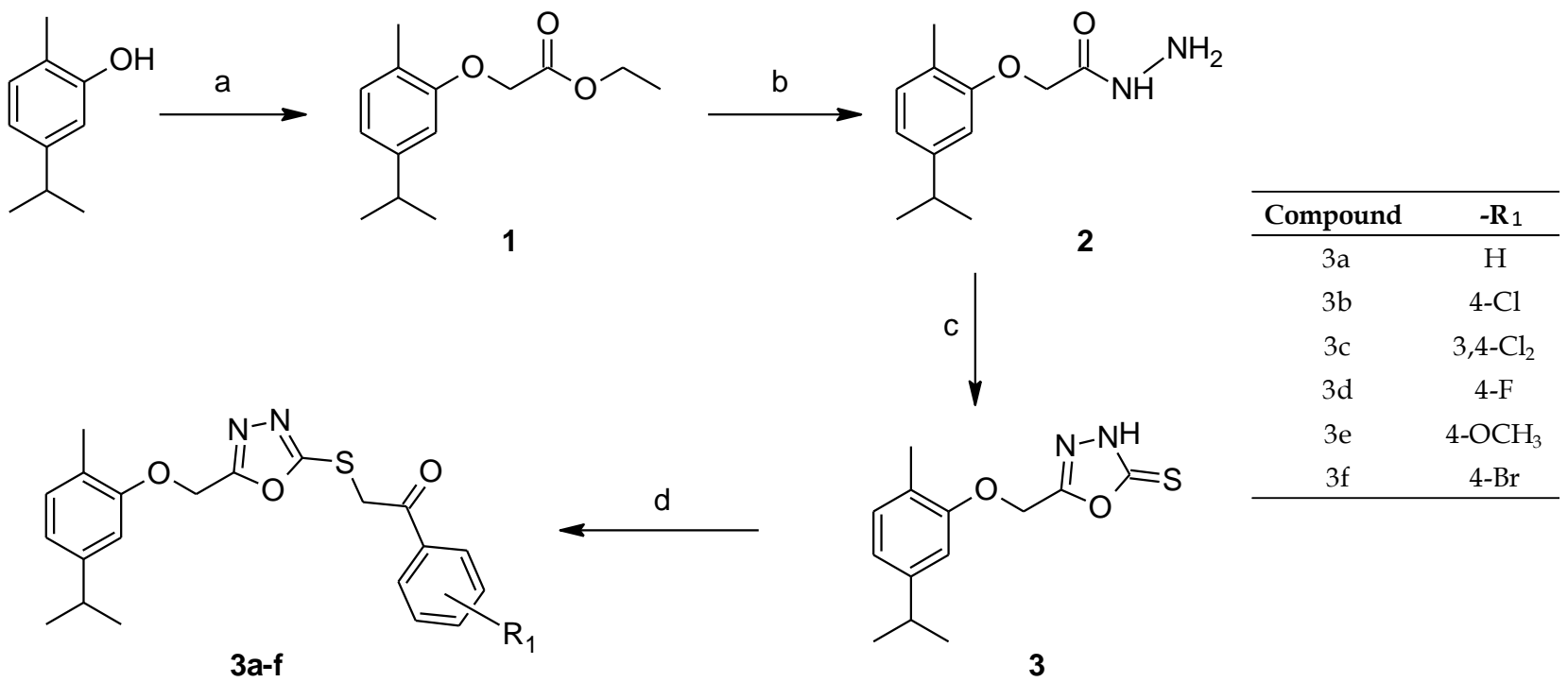

Figure 3. Synthetic route to compounds 3a-f. Key to reagents: a. $\mathrm{BrCH}_{2} \mathrm{COOC}_{2} \mathrm{H}_{5}, \mathrm{~K}_{2} \mathrm{CO}_{3}$, acetone; b. $\mathrm{NH}_{2} \mathrm{NH}_{2}$. $\mathrm{H}_{2} \mathrm{O}$, $\mathrm{EtOH}_{\text {; }}$ c. $\mathrm{KOH}, \mathrm{CS}_{2}$, EtOH, $\mathrm{HCl}$; d. TEA, acetonitrile, $\alpha$-bromoacetophenone derivatives.

All synthesized compounds were checked for purity using TLC, HPLC-UV/DAD and elemental analysis. All compounds were characterized by their melting points, IR, ${ }^{1} \mathrm{H}-\mathrm{NMR}$. All ethanone derivatives were (3a-f) also characterized with LR-MS spectral data to confirm correct molecular ion peaks corresponding to $(\mathrm{M}+\mathrm{H})^{+}$in positive ionization and $(\mathrm{M}-\mathrm{H})^{-}$in negative ionization modes for each compound. For compounds $3 \mathbf{a}$ and $\mathbf{3 b}, \mathrm{HMBC}$ data also recorded.

The $\mathrm{C}=\mathrm{O}$ stretching band of compound 2, which was detected at $1666 \mathrm{~cm}^{-1}$ disappeared by the cyclization of this compound to 1,3,4-oxadiazole derivative. The $\mathrm{N}-\mathrm{H}, \mathrm{C}=\mathrm{N}$ and $\mathrm{C}=\mathrm{S}$ stretching bands were observed at 3178, 1610 and $1276 \mathrm{~cm}^{-1}$, respectively. 1,3,4-Oxadiazole-2-thiones may exist in thiole or thione forms. According to the literature, S-H stretching band was observed at $2600-2500 \mathrm{~cm}^{-1}$ values and absence of these bands at IR spectrum of compound 3, indicated that this compound should exist in thione tautomeric 
form [50]. To determine 3D structure of newly synthesized 1,3,4-oxadiazol derivatives, X-Ray crystallography was reported to be carried out and $C=S$ bond length was found consistent with the literature findings [51]. Spectroscopic data also supported that 1,3,4-oxadiazole derivatives may exist in thione form rather than thiole form [52].

The N-H proton of compound 3 was detected at $14.69 \mathrm{ppm}$ in accordance with literature [53] while the $\mathrm{S}-\mathrm{H}$ proton was reported at 1.6-2.0 ppm [54]. The most important proof of the formation of ketone structure, the $\mathrm{C}=\mathrm{O}$ stretching bands of compounds 3a-f which were detected at $1685-1658 \mathrm{~cm}^{-1}$. The disappearance of $\mathrm{C}=\mathrm{S}$ band and appearance of $\mathrm{S}-\mathrm{CH}_{2-}$ protons at 5.07-5.14 ppm are other evidences of this formation.

The HMBC spectra of $\mathbf{3} \mathbf{a}$ and $\mathbf{3} \mathbf{b}$ were taken to identify the interactions between atoms linked by two or three bond distances (Figure 4). Based on the HMBC spectrum of 3a, the correlations between C16 (192.67 ppm) and H15 (5.14 ppm) and H18 (8.04 ppm) are one of the important ones. The correlations between H15 (5.14 ppm) and C14 (164.84), correlations between H10 (5.37 ppm) and C13 (164.42 ppm), can be seen at Figure 4. The correlations between one of the aromatic protons H18 (8.04 ppm) and C16 (192.67 ppm), C19 (128.91 ppm), C20 (134.46 ppm), H19 (7.57 ppm) and C17 (135.46 ppm), C18 (129.36 ppm), C20( 134.46 ppm), between H3 (6.96 ppm) and C1 (124.03 ppm), C2 (155.79 ppm), C4 (148.08 ppm), C5 (119.77 ppm), between H5 and C1( 124.03 ppm), C2 (155.79 ppm), C3 (111.27 ppm), C6 (130.95 ppm), between H6 and C1 (124.03 ppm), C2 (155.79 ppm), C3 (111.27 ppm), C4 (148.08 ppm) were also indicated in the Figure 4.

The HMBC spectrum of $\mathbf{3 b}$ has similar results like compound 3a. The correlations between C16 (191.85 ppm) and H15 (5,12 ppm) and H18 (8.06 ppm) were observed. The correlations between H15 (5.12 ppm), C14 (164.77 ppm), the correlations between H10 (5.37 ppm) and C13 (164.45 ppm), the correlations between H18 (8.06 ppm) and C16 (191.85 ppm), C19 (129.59 ppm), C20 (139.43 ppm), the correlations between H19 (7.66 ppm) and C17 (134.15 ppm), C18 (130.82 ppm) and C20 (139.43 ppm) were identified.

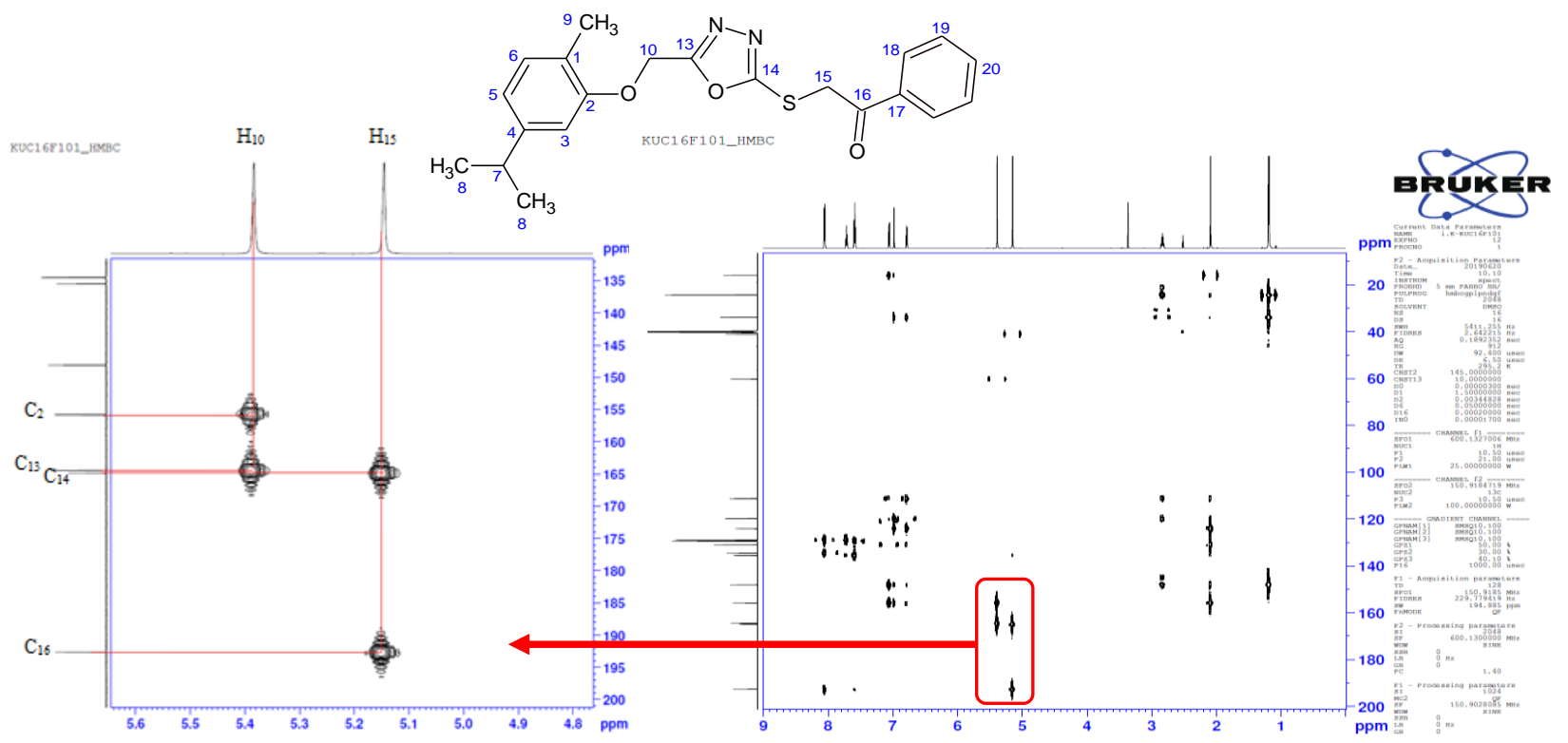

Figure 4. HMBC spectrum of compound 3a (correlations between 135-200 ppm and 4.8-5.6 ppm).

\subsection{Anticancer activity}

The anticancer activity of synthesized compounds was evaluated on MCF-7 (breast), A549 (lung), PC-3 (prostate), cervics (HeLa) and K562 (chronic myeloid leukemia) cell lines and murine fibroblast NIH3T3 cell line at $10 \mu \mathrm{M}$ (Table 1). None of the compounds showed significant inhibition against these cell lines. Therefore, none of the compounds were selected for further testing. The starting compound $\mathbf{3}$ did not show promising inhibition as well as all thioether derivatives. It is expected that a drug candidate should be cyctotoxic to cancer cells but healthy cells. The cyctotoxicity of newly synthesized compounds were evaluated against NIH3T3 mouse embriyonic fibroblasts. Percent inhibition value range of thioether derivatives appears between 2.01 and $32.61 \%$. As none of the compounds exhibited remarkable inhibition at $10 \mu \mathrm{M}$, no further anticancer screening has been made on these compounds. 
Table 1. In vitro cytotoxic effects of compounds 3 and 3a-f against human cancer cell lines and normal cell line.

\begin{tabular}{ccccccccc}
\hline \multirow{2}{*}{ Compound } & Lab ID Code & \multirow{2}{*}{$\mathbf{R}_{\mathbf{1}}$} & \multicolumn{3}{c}{ \% Proliferation } \\
\cline { 4 - 9 } & & - & MCF-7 & A549 & PC-3 & HeLa & K562 & NIH3T3 \\
\hline 3 & KUC16F101 & H & 90.75 & 112.60 & 107.22 & 96.85 & 108.40 & 93.39 \\
3a & KUC16F104 & $4-\mathrm{Cl}$ & 88.14 & 71.67 & 81.16 & 92.43 & 95.72 & 97.99 \\
3b & KUC16F106 & $3,4-\mathrm{Cl}_{2}$ & 109.35 & 85.58 & 122.76 & 98.13 & 95.14 & 91.51 \\
3c & KUC16F109 & $4-\mathrm{F}$ & 107.91 & 91.50 & 98.17 & 103.01 & 101.18 & 67.39 \\
3d & KUC16F111 & $4-\mathrm{OCH}$ & 114.62 & 73.79 & 80.77 & 112.62 & 142.20 & 87.63 \\
3e & KUC16F115 & $4-\mathrm{Br}$ & 85.95 & 80.75 & 80.93 & 96.17 & 95.09 & 102.43 \\
3f & - & - & - & - & - & - & 40.46 & 148.83 \\
Imatinib & - & - & 31.53 & 22.43 & 15.56 & 38.63 & - & 83.78 \\
Docetaxel & & & & & &
\end{tabular}

\subsection{Inhibition of mPGES-1 and COX-1/2 enzymes}

Compounds 3a-f were screened for mPGES-1 inhibitory activity (Table 2). MK-886 and $\mathbf{4 b}$ were used as reference compounds and $\mathrm{IC}_{50}$ values for these compounds were found as $2.58 \pm 0.48$ and $0.034 \pm 0.014 \mu \mathrm{M}$, respectively. Compounds that caused an inhibition greater than $70 \%$ at $10 \mu \mathrm{M}$ were further screened at a concentration of $1 \mu \mathrm{M}$. IC 50 values were determined only for the compounds that showed $\geq 70 \%$ inhibition at $10 \mu \mathrm{M}$. Among all of the synthesized compounds, 3a showed significant inhibitory activity against mPGES-1 enzyme at concentration at an $\mathrm{IC}_{50}$ value of $4.95 \pm 2.07 \mu \mathrm{M}$. Compound $3 \mathrm{a}$ were determined as a lead compound with its inhibitory potential comparable to the reference compound MK-886 which was demonstrated bioactive mPGES-1 inhibitor [46]. It was interesting that, this unique compound has no substitution at $\mathrm{R}_{1}$ position and substitution at this location resulted in the loss of activity.

Since both mPGES-1 and COX enzymes have similar membrane embedded configuration [5] and they are both macromolecular targets for inhibition of $\mathrm{PGE}_{2}$ synthesis, inhibition assay was carried out for COX enzymes too. As a next step for compound 3a, which showed remarkable inhibition against mPGES-1, we intended to find out whether it has significant inhibitory activity against either COX-1 or COX-2. Inhibition potency of compound 3a were determined at $100 \mu \mathrm{M}$ and found as 58.86 and $83.26 \mu \mathrm{M}$ values for COX-1 and COX-2, respectively. Although this compound had an inhibitory potency at high concentration, this inhibition was not found significantly selective.

Table 2. mPGES-1 inhibition results for 3a-f.

\begin{tabular}{|c|c|c|c|c|c|c|}
\hline Compound & $\begin{array}{l}\text { Lab ID } \\
\text { Code }\end{array}$ & $\mathbf{R}_{\mathbf{1}}$ & $\begin{array}{c}\text { mPGES-1 \% } \\
\text { inhibition } \\
\text { at } 10 \mu \mathrm{M} \text { a }\end{array}$ & $\begin{array}{l}\text { mPGES-1 } \\
\text { IC }_{50}(\mu \mathrm{M}){ }^{b}\end{array}$ & $\begin{array}{c}\text { COX-1 \% } \\
\text { inhibition } \\
\text { at } 100 \mu \mathrm{M}\end{array}$ & $\begin{array}{c}\text { COX-2\% } \\
\text { inhibition } \\
\text { at } 100 \mu \mathrm{M}\end{array}$ \\
\hline $3 a$ & KUC16F101 & $\mathbf{H}$ & $78 \pm 7.6$ & $4.95 \pm 2.07$ & 58.86 & 83.26 \\
\hline $3 b$ & KUC16F104 & 4-Cl & $40.4 \pm 4.9$ & - & - & - \\
\hline $3 c$ & KUC16F106 & $3,4-\mathrm{Cl}_{2}$ & $6.5 \pm 0.2$ & - & - & - \\
\hline $3 d$ & KUC16F109 & $4-F$ & $28 \pm 2.5$ & - & - & - \\
\hline $3 e$ & KUC16F111 & $4-\mathrm{OCH}_{3}$ & $23 \pm 2.1$ & - & - & - \\
\hline $3 f$ & KUC16F115 & $4-\mathrm{Br}$ & $30 \pm 7.3$ & - & - & - \\
\hline MK-886 c & & & & $2.58 \pm 0.48$ & & \\
\hline $4 b^{c}$ & & & & $0.034 \pm 0.014$ & & \\
\hline
\end{tabular}

\footnotetext{
${ }^{a}$ Data are expressed as means \pm SD of single determinations obtained in triplicate.

${ }^{b} \mathrm{IC}_{50}$ values were determined only for the compounds that showed $\geq 70 \%$ inhibition at $10 \mu \mathrm{M}$. Data are expressed as means \pm SD of single determinations obtained in triplicate.

${ }^{c}$ Compounds MK-886 and $4 \mathrm{~b}$ were used as reference compounds for the determination of IC 50 values. MK-886 is a wellrecognized inhibitor against mPGES-1 and $\mathbf{4 b}$ is the inhibitor developed by Chang Guo Zhan's lab [45]. Structures of MK-886 and compound $\mathbf{4 b}$ were given in Figure 1.
} 


\subsection{In silico docking studies}

Computer-assisted molecular modelling techniques have been used to estimate the possible inhibitory activities and mechanism of binding to COX enzymes and mPGES-1 enzyme of the synthesized compounds $[55,56]$. Binding energy was obtained from the docking studies of the compounds 3a-f by using Autodock4.2. [57]. The results were given in Table 3 . Compound $\mathbf{3 b}$ showed slightly higher binding affinity than that of others for mPGES-1 with a predicted binding energy value of $-6.61 \mathrm{kcal} / \mathrm{mol}$, and an estimated constant inhibition value of $14.18 \mu \mathrm{M}$. Compound $3 \mathrm{~b}$ were found to be interacted with glutathione by a halogen

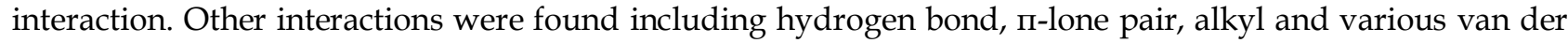
Waals interactions (Figure 5 (a)). Especially halogen substitution at $R_{1}$ position have been observed to increase calculating binding affinity, probably by providing further halogen interactions by GSH and TYR residues.

In addition, Compound $\mathbf{3 b}$ displayed the highest binding affinity for COX-1 with a predicted binding energy value of $-11 \mathrm{kcal} / \mathrm{mol}$, and an estimated constant inhibition value of $8.68 \mathrm{nM}$. Compound $3 \mathbf{b}$ displayed two H-bonds, $\Pi-\sigma$ bond, $\Pi-S u l f u r$, alkyl and many van der Waals interactions (Figure 5 (b)). Lastly, compound $3 \mathbf{c}$ had the highest binding affinity for COX-2 with a calculated binding energy value of $-11.54 \mathrm{kcal} / \mathrm{mol}$, and an estimated constant inhibition value of $3.49 \mathrm{nM}$. Compound $3 \mathrm{c}$ showed the highest number of hydrophobic (alkyl) and hydrogen bonds interactions which contributed to the highest affinity and lowest binding energy $(-11.54 \mathrm{kcal} / \mathrm{mol})$ among all docked compounds. Also, compound $3 \mathrm{c}$ depicted amide- $\Pi$ and multiple van der Waals interactions (Figure 5 (c)). Most of the interactions within these complexes were $\Pi$-alkyl, $\Pi$-sulfur and hydrogen bonds.

Table 3. Docking results of compounds 3a-f.

\begin{tabular}{|c|c|c|c|c|c|c|c|}
\hline \multirow{2}{*}{ Compound } & \multirow{2}{*}{$\mathbf{R}_{\mathbf{1}}$} & \multicolumn{2}{|c|}{ PGES-1 } & \multicolumn{2}{|c|}{ COX-1 } & \multicolumn{2}{|c|}{ COX-2 } \\
\hline & & $\Delta \mathrm{G}^{\mathrm{a}}$ & $\mathbf{K} i(\mu \mathrm{M}) \mathbf{b}$ & $\Delta \mathbf{G}$ & $\mathbf{K} \boldsymbol{i}(\mathrm{nM})$ & $\Delta \mathrm{G}$ & $\mathbf{K} i(\mathrm{nM})$ \\
\hline $3 a$ & $\mathrm{H}$ & -6.21 & 28.14 & -10.36 & 25.53 & -11.32 & 5.02 \\
\hline $3 b$ & $4-\mathrm{Cl}$ & -6.61 & 14.18 & -11.00 & 8.68 & -11.02 & 8.41 \\
\hline $3 c$ & $3,4-\mathrm{Cl}_{2}$ & -6.52 & 16.62 & -10.38 & 24.79 & -11.54 & 3.49 \\
\hline $3 d$ & $4-\mathrm{F}$ & -6.09 & 34.38 & -10.19 & 33.65 & -10.34 & 26.38 \\
\hline $3 \mathbf{e}$ & $4-\mathrm{OCH}_{3}$ & -5.95 & 43.39 & -9.79 & 66.37 & -10.81 & 11.86 \\
\hline $3 f$ & $4-\mathrm{Br}$ & -6.55 & 15.86 & -10.85 & 11.14 & -11.28 & 5.40 \\
\hline
\end{tabular}

a Binding affinity ( $\mathrm{kcal} / \mathrm{mol})$.

b Inhibition constant.

\subsection{In silico prediction of potential ADME and drug-like properties}

ADME properties were calculated using SwissADME online tool program [58] and the results were given in Table 4 . $\log P$ is an important physicochemical property for drug discovery and should be $<5$ due to Lipinski's rule of five. Results showed that all compounds showed compatibility with the acceptable criteria except 3c, with a $\log \mathrm{P}$ value slightly higher than 5 . Solubility is another important property for drug candidate in order to maintain oral administration and absorption and expressed as Log S. Polar surface area (PSA) and topological polar surface area (TPSA) are important criteria for crossing biological barriers such as blood brain barrier and the value should be smaller than $140 \AA$. In order to achieve a flexible molecule number of rotatable bands should be smaller than 10. Estimated intestinal absorption calculated with this formula: \%ABS=109$(0.345 \times$ TPSA) according to literature [59]. 

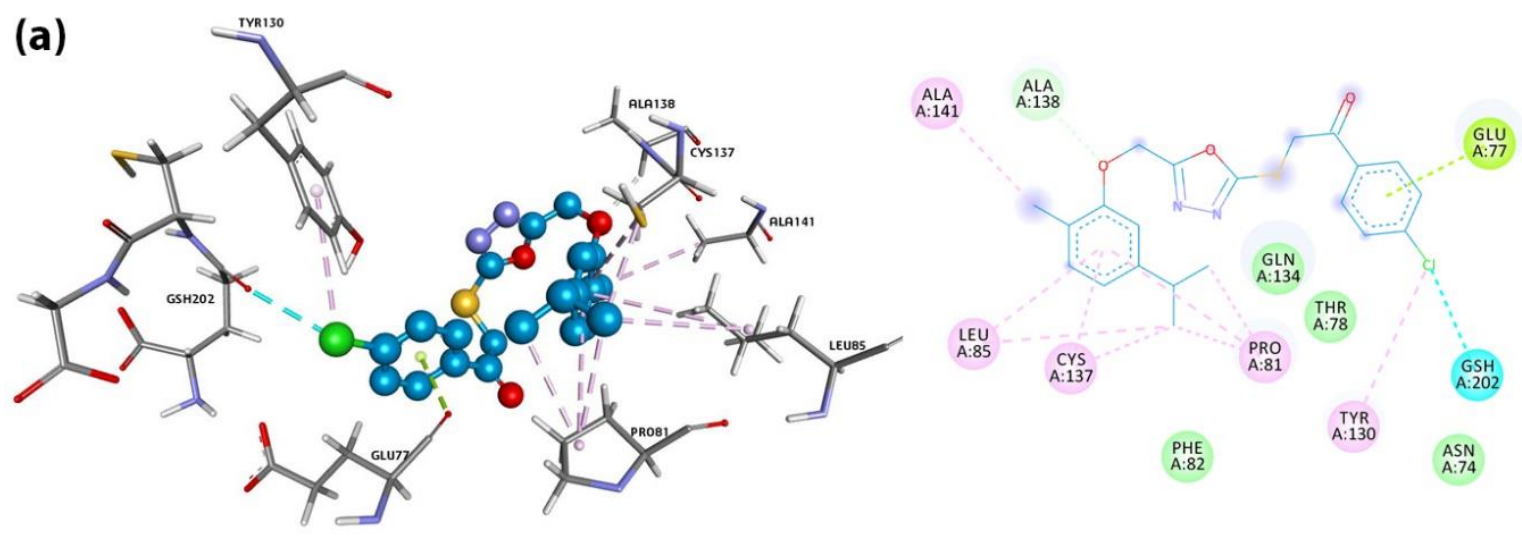

(b)
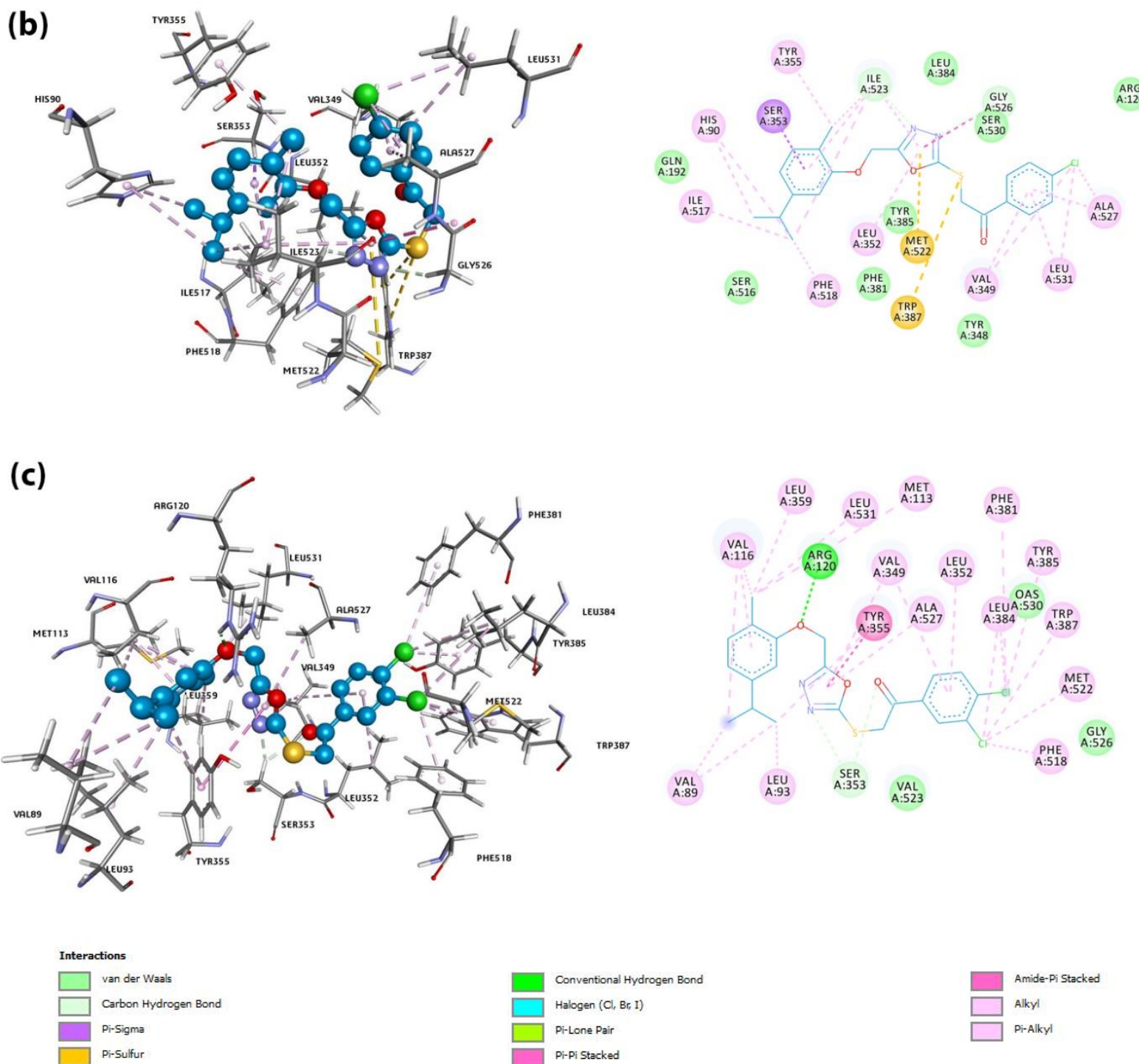

Figure 5. 3D and 2D pictures of the compound $3 \mathbf{b}$ in the active site of mPGES- 1 enzyme (a), $3 \mathbf{b}$ complexed with the active site of COX-1 (b) and compound $3 \mathbf{c}$ bound to the binding site of COX-2 (c). 
All compounds pass the Lipinski's Rule of 5. Water solubility is an important factor for the drug development. Water solubility value of our compounds are poor (log $S$ value between -7.76 and -8.83 ). The absorption percent of all thioether derivatives are $77.77 \%$ except compound $3 \mathbf{e}(74.59 \%)$ and this is an indication of acceptable bioavailability by oral route $(>50 \%)$. Topological polar surface area is the surface of polar atoms ranging between 90.52 and 99.75 for all compounds which indicates low blood-brain barrier penetration, therefore CNS based side effects could not be anticipated. All the tested compounds having less than 10 rotatable bonds which leads to low conformational flexibility. Molar refractivity index is less than 130 for all compounds (106.26-113.96). P-glycoprotein (P-gp) is an ATP-dependent transmembrane protein and have a role in drug transportation. It has excessively found in tumor cells and caused to multi drug resistance. It also can be found in healthy tissues such as liver, kidney, small intestine, colon, brain, heart, peripheral nerves as well as blood-brain and blood-testicular barrier. In the tissues that play a role in ADME properties such as small intestine, central nervous system, liver and kidney, the P-gp expression was found high and that causes to changes pharmacokinetics-toxicokinetics of the substrates of P-gp [60, 61]. The results obtained showed that none of our compounds are a substrate for P-gp. All of compounds are predicted as inhibitors of CYP2C19, CYP2C9, CYP3A4 and as a non-inhibitor for CYP2D6. In Figure 5, the prediction of intestinal absorption and blood-brain barrier penetration is given in the form of boiled egg model. In this model, the yellow area indicates well penetration for brain and intestinal absorption. The white area indicates intestinal absorption and lastly grey area indicates poor intestinal absorption [62]. None of our compounds located in the blood-brain barrier penetration area. But all our compounds located in white area which associated with potential intestinal absorption. All synthesized compounds have similar bioavailability score (0.55).

In conclusion these drug-likeness results indicated that, the 1,3,4-oxadiazole-thioether derivatives show good potential for their pharmacokinetic properties, but no blood-brain barrier penetration. All the predicted parameters are within the range of accepted values. However, further optimization needs to continue on prospective compounds, in order to achieve better ADME properties such as solubility.

Table 4. Predicted ADME properties of compounds 3a-f.

\begin{tabular}{|c|c|c|c|c|c|c|}
\hline \multirow{2}{*}{ ADME Properties a } & \multicolumn{6}{|c|}{ Compounds } \\
\hline & $3 a$ & $3 b$ & $3 c$ & $3 d$ & $3 e$ & $3 f$ \\
\hline$M W \leq 500$ & 382.48 & 416.92 & 451.37 & 400.47 & 412.50 & 461.37 \\
\hline CLP $<5$ & 4.36 & 4.90 & 5.39 & 4.70 & 4.43 & 4.99 \\
\hline $\log S \geq-4$ & -7.66 & -8.24 & -8.83 & -7.92 & -7.76 & -8.44 \\
\hline $\mathrm{RB} \leq 10$ & 8 & 8 & 8 & 8 & 9 & 8 \\
\hline $\mathrm{HD} \leq 5$ & 0 & 0 & 0 & 0 & 0 & 0 \\
\hline $\mathrm{HA} \leq 10$ & 5 & 5 & 5 & 6 & 6 & 5 \\
\hline MR 40-130 & 106.26 & 111.27 & 116.28 & 106.22 & 112.75 & 113.96 \\
\hline$\%$ ABS & 77.77 & 77.77 & 77.77 & 77.77 & 74.59 & 77.77 \\
\hline TPSA $\leq 140 \AA$ & 90.52 & 90.52 & 90.52 & 90.52 & 99.75 & 90.52 \\
\hline GI absorption & High & High & High & High & High & High \\
\hline P-gp substrate & No & No & No & No & No & No \\
\hline BBB penetration & No & No & No & No & No & No \\
\hline Skin permeation $(\log \mathrm{Kp})$ & -5.08 & -4.85 & -4.62 & -5.12 & -5.29 & -5.07 \\
\hline CYP1A2 inhibitor & Yes & Yes & No & Yes & Yes & Yes \\
\hline CYP2C9 inhibitor & Yes & Yes & Yes & Yes & Yes & Yes \\
\hline CYP2C19 inhibitor & Yes & Yes & Yes & Yes & Yes & Yes \\
\hline CYP2D6 inhibitor & No & No & No & No & No & No \\
\hline CYP3A4 inhibitor & Yes & Yes & Yes & Yes & Yes & Yes \\
\hline Bioavailability score & 0.55 & 0.55 & 0.55 & 0.55 & 0.55 & 0.55 \\
\hline
\end{tabular}

a Parameter calculated using SwissADME (http://www.swissadme.ch).

MW:molecular weight, CLP: cLOGP, logS:solubility, RB: number of rotatable bonds, HD: number of hydrogen donors, HA: number of hydrogen acceptors, MR: molar refractivity, TPSA: topological polar surface area. 


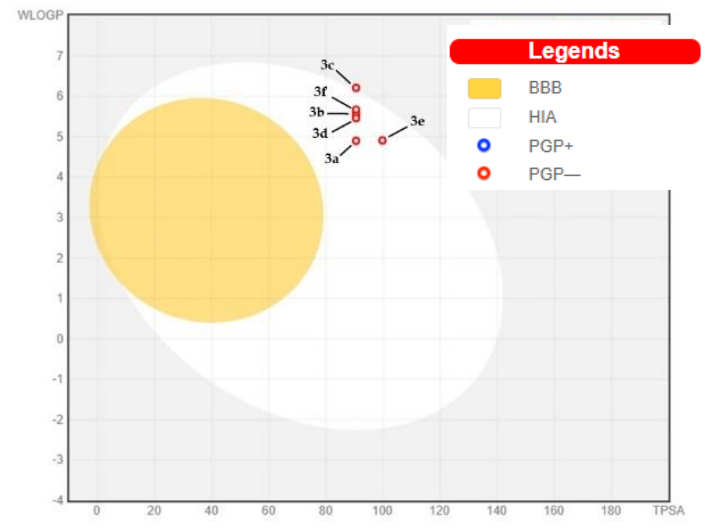

Figure 5. Boiled-egg prediction chart of compounds 3a-f.

\section{CONCLUSION}

Despite COXs enzymes are important target for the prevention of inflammation, long term use of COXs inhibitors can cause several side effects. mPGES-1 is a potential target in order to inhibit $\mathrm{PGE}_{2}$ synthesis in inflammatory stimuli and its inhibition also related with other diseases such as cancer. In this study we described the synthesis of six new 2-aryloxymethyl-1,3,4-oxadiazole derivatives as potential inhibitors of mPGES-1 enzyme. Compound 3a was identified as the most potent agent against this enzyme with $\mathrm{IC}_{50}$ value of $4.95 \mu \mathrm{M}$. This compound also showed inhibition against COX-2 enzyme greater than $82 \%$. According to docking studies of compound $\mathbf{3 b}$, chlorine substituent at $\mathrm{R}_{1}$ position estimated slightly higher binding affinity than compound 3a to mPGES-1 enzyme. It can be observed from 2D picture of compound $\mathbf{3} \mathbf{b}$, most of the interactions occurred between the carvacrol-based part of the compound and mPGES-1 enzyme active site. Another pi-lone pair interaction occurred between the second phenyl ring of the compound and enzyme active site. The reason why there is no reliable correlation between mPGES-1 inhibitory activities (percent inhibitions) and the docking scores indicates that there might be other factors except direct interactions of compounds 3af with enzyme active site. These factors can be related to poor solubility of chlorinated and brominated derivatives and potential steric effects caused by these substituents. It has been observed that the carvacrol structure is important for interaction with the enzyme. Therefore, future studies on novel carvacrol derivatives are being followed these steps.

\section{MATERIALS AND METHODS}

\subsection{Chemicals and instruments}

All solvents and reagents were obtained from commercial sources and used without further purification. The purity of the compounds was confirmed by the thin-layer chromatography (TLC) performed on Merck silica gel 60 F254 aluminium sheets (Merck, Darmstadt, Germany), using developing systems: S1: chloroform/methanol/acetic acid $(8: 2: 400 \mu \mathrm{L} \mathrm{v} / \mathrm{v} / \mathrm{v})$, S2: petroleum ether/ethyl acetate $(5: 5 \mathrm{v} / \mathrm{v})$, S3: petroleum ether/ethyl acetate $(7: 3 \mathrm{v} / \mathrm{v})$. Spots were detected under UV light at $254 \mathrm{~nm}$. All melting points were determined using Thermo Scientific IA9300 basic model point apparatus and are uncorrected. Elemental analyses were obtained using Leco CHNS-932 and are consistent with the assigned structures. Infrared spectra (IR) were recorded on a Shimadzu FT-IR 8400s and data is expressed in wavenumbers $\left(\mathrm{cm}^{-1}\right)$. NMR spectra were recorded on Bruker AVANCE DPX $300 \mathrm{MHz}$ for ${ }^{1} \mathrm{H}$ NMR and $150 \mathrm{MHz}{ }^{13} \mathrm{C}$ NMR. The chemical shifts were expressed in ppm (parts per million) downfield from tetramethylsilane (TMS) using DMSO- $\mathrm{d}_{6}$ as solvent. The high-pressure liquid chromatographic system consists of a Shimadzu LC-20AT series instrument equipped with quaternary solvent delivery system and a model SPD-M20A PDA detector. A Rheodyne syringe loading sample injector with $50 \mu \mathrm{L}$ sample loop was used for the injection of the analytes. Chromatographic data were collected and processed using Shimadzu LabSolutions software. The separation was performed at ambient temperature by using reversed phase GL Sciences Inertsil ODS-3 $(4.6 \times 250 \mathrm{~mm}$, $5 \mu \mathrm{m})$ column. All experiments were performed in isocratic mode. The mobile phase was prepared by mixing acetonitrile and water $(7: 3, \mathrm{v} / \mathrm{v})$ and filtered through a $0.45 \mathrm{~mm}$ pore filter and subsequently degassed by ultrasonication, prior to use. Solvent delivery was employed at a flow rate of $1 \mathrm{~mL} / \mathrm{min}$. Detection of the analytes was carried out at $254 \mathrm{~nm}$. SMILES codes of the compounds were generated from the structures using the ACD/ChemSketch version 12.0 molecular editor [63] and then physicochemical properties were calculated by using SwissADME calculation software [58]. 


\subsection{Chemistry}

\subsubsection{Synthesis of ethyl-2-[2-methyl-5-(propan-2-yl)phenoxy]acetate (1)}

Carvacrol $(0.06 \mathrm{~mol})$ and anhydrous potassium carbonate $(0.09 \mathrm{~mol})$ were dissolved in dry acetone and heated under reflux for 4 hours. Upon cooling temperature, followed by dropwise addition of ethyl bromoacetate $(0.063 \mathrm{~mol})$ for 1 hour, refluxing continued for another 8 hours. The excess solvent was removed, and crushed ice added to deposit. The mixture was stirred for half an hour and extracted with diethyl ether. The organic layer was washed with water and dried with $\mathrm{Na}_{2} \mathrm{SO}_{4}$. The solvent was recovered under vacuum and yellowish oil obtained. This compound was used in the next step without purification [16, 49]. HPLC $t_{R}$ (min): 13.92, TLC Rf: 0.74 (S1) yield 80\%. IR cm ${ }^{-1}: 1760$ (C=O), 1197 (C-O-C). ${ }^{1} \mathrm{H}$ NMR (300 MHz, DMSO-d $)$ :

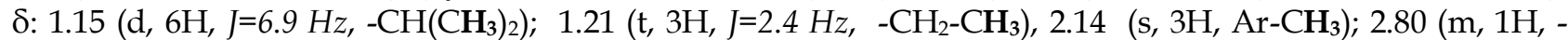
$\left.\mathrm{CH}\left(\mathrm{CH}_{3}\right)_{2}\right) ; 4.17\left(\mathrm{q}, 2 \mathrm{H},-\mathrm{CH}_{2}-\mathrm{CH}_{3}\right) ; 4.78\left(\mathrm{~s}, 2 \mathrm{H},-\mathrm{O}-\mathrm{CH}_{2}-\right) ; 6.68$ (s, 1H, Ar-H), 6.73 (d, 1H, J=7.8 Hz, Ar-H); 7.04 (d, $1 \mathrm{H}, J=7.8 \mathrm{~Hz}, \mathbf{A r}-\mathbf{H})$.

\subsubsection{Synthesis of 2-[2-methyl-5-(propan-2-yl)phenoxy]acetohydrazide (2)}

Compound 1 (0.03 mol) and hydrazine hydrade $(0.06 \mathrm{~mol})$ in $20 \mathrm{~mL}$ ethanol refluxed for 2 hours. Progress of reaction was monitored with TLC. Then the solution was cooled, filtered, dried and recrystallized from ethanol: water mixture [49]. $\mathrm{HPLC}_{\mathrm{R}}(\mathrm{min}): 4.38, \mathrm{M} . \mathrm{p}: 128-130{ }^{\circ} \mathrm{C}, \mathrm{TLC} \mathrm{R}_{\mathrm{f}}: 0.29$ (S1), yield $73 \%$. IR cm-1: 3309 and 3200 (N-H str), 1666 (C=O), 1H NMR (300 MHz, DMSO-d6): $\delta: 1.17$ (d, 6H, J=6.9 Hz, -CH(CH )2); 2.14 (s, 3H, Ar- $\left.\mathrm{CH}_{3}\right) ; 2.80\left(\mathrm{~m}, 1 \mathrm{H},-\mathrm{CH}\left(\mathrm{CH}_{3}\right)_{2}\right) ; 4.34$ (s, 2H, - $\mathrm{NH}_{2}$ ) ; 4.48 (s, 2H, -O-CH2-); 6.78 (m, $\left.2 \mathrm{H}, \mathbf{A r}-\mathbf{H}\right)$; 7.04 (d, 1H, J=9 Hz, Ar-H); 9.20 (s, 1H, CO-NH-). Anal. Calcd. for $\mathrm{C}_{12} \mathrm{H}_{18} \mathrm{~N}_{2} \mathrm{O}_{2}: \mathrm{C}, 64.84 ; \mathrm{H}, 8.16$; N,12.60. Found: C, 63.34; H, 7.49; N, 12.35 .

\subsubsection{Synthesis of 5-\{[2-Methyl-5-(propan-2-yl)phenoxy]methyl\}-1,3,4-oxadiazole-2-(3H)-thione (3)}

Compound $2(0.01 \mathrm{~mol})$ and $\mathrm{KOH}(0.01 \mathrm{~mol})$ were dissolved in $40 \mathrm{~mL}$ absolute ethanol and $0.02 \mathrm{~mol} \mathrm{CS}_{2}$ was added to this solution and refluxed for 4 hours. After reaction completed the solution was cooled to the room temperature and diluted with iced water and neutralized with $10 \% \mathrm{HCl}$. The precipitated compound filtered, dried and recrystallized from petroleum ether [64]. HPLC $t_{R}(\mathrm{~min}): 6.84, \mathrm{M} . \mathrm{p}: 136-138^{\circ} \mathrm{C}, \mathrm{TLC}_{\mathrm{f}}: 0.46$ (S2), yield 56\%. IR cm ${ }^{-1}: 3178$ (N-H str), $1610(\mathrm{C}=\mathrm{N}), 1276$ (C=S). ${ }^{1} \mathrm{H}$ NMR (300 MHz, DMSO-d $): \delta: 1.19$ (d, $\left.6 \mathrm{H}, \mathrm{J}=6.9 \mathrm{~Hz},-\mathrm{CH}\left(\mathrm{CH}_{3}\right)_{2}\right) ; 2.12\left(\mathrm{~s}, 3 \mathrm{H}, \mathrm{Ar}-\mathrm{CH}_{3}\right) ; 2.76-2.90\left(\mathrm{~m}, 1 \mathrm{H},-\mathrm{CH}\left(\mathrm{CH}_{3}\right)_{2}\right) ; 5.26\left(\mathrm{~s}, 2 \mathrm{H},-\mathrm{O}-\mathrm{CH} 2^{-}\right)$; $6.80(\mathrm{~d}$, 1H, J=6.7 Hz, Ar-H); 6.96 (s, 1H, Ar-H); 7.07 (d, 1H, J=7.2 Hz, Ar-H); 14.69 (s, 1H, N-H). Anal. Calcd. for $\mathrm{C}_{13} \mathrm{H}_{16} \mathrm{~N}_{2} \mathrm{O}_{2} \mathrm{~S}: \mathrm{C}, 59.07 ; \mathrm{H}, 6.10 ; \mathrm{N}, 10.60$. Found: C, 59.25; H, 6.43; N, 10.13 .

\subsubsection{General synthesis of compounds 3a-f}

An equimolar mixture of compound 3 and substituted phenacyl bromide $(0.01 \mathrm{~mol})$ and TEA (0.012 $\mathrm{mol})$ in acetonitrile $(50 \mathrm{~mL})$ was heated under reflux for 4-8 h. The reaction mixture was evaporated to dryness. The residue was crystallized from aqueous ethanol affording the pure products [22].

2-[5-\{[2-Methyl-5-(propan-2-yl)phenoxy]methyl\}-1,3,4-oxadiazol-2-yl)sulphanyl]-1-(phenyl)ethan-1-one (3a): It was obtained as a light yellow solid. HPLC $t_{R}(\mathrm{~min}): 18.05$, M.p: $99-101{ }^{\circ} \mathrm{C}$, TLC $\mathrm{R}_{\mathrm{f}}: 0.77(\mathrm{~S} 3)$, yield $69 \% . \mathrm{IR} \mathrm{cm}^{-1}$ :

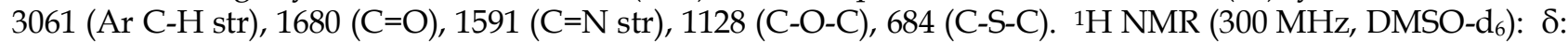
$1.17(\mathrm{~d}, 6 \mathrm{H}, \mathrm{J}=6.9 \mathrm{~Hz},-\mathrm{CH}(\mathrm{CH} 3) 2) ; 2.07$ (s, 3H, Ar- $\left.\mathrm{CH}_{3}\right) ; 2.77-2.87\left(\mathrm{~m}, 1 \mathrm{H},-\mathrm{CH}\left(\mathrm{CH}_{3}\right)_{2}\right) ; 5.14\left(\mathrm{~s}, 2 \mathrm{H},-\mathrm{S}-\mathrm{CH} \mathbf{2}^{-}\right)$; 5.37 (s, 2H, $\left.-\mathrm{O}-\mathrm{CH}_{2^{-}}\right) ; 6.76(\mathrm{dd}, 1 \mathrm{H}, J=7.5 \mathrm{~Hz}, J=1.2 \mathrm{~Hz}, \mathbf{A r}-\mathbf{H}) ; 6.96(\mathrm{~d}, 1 \mathrm{H}, J=1.2 \mathrm{~Hz}, \mathbf{A r}-\mathbf{H}) ; 7.05$ (d, $1 \mathrm{H}, J=7.8$ $\mathrm{Hz}, \mathrm{Ar}-\mathrm{H}) ; 7.57(\mathrm{t}, 1 \mathrm{H}, J=7.5 \mathrm{~Hz}, \mathrm{~J}=1.5 \mathrm{~Hz}, \mathbf{A r}-\mathbf{H}) ; 8.04(\mathrm{dd}, 1 \mathrm{H}, J=7.5 \mathrm{~Hz}, J=1.5 \mathrm{~Hz}, \mathbf{A r}-\mathbf{H}) .{ }^{13} \mathrm{C}-\mathrm{NMR}(150 \mathrm{MHz}$, DMSO-d $)$ : $\delta: 15.89,24.32,33.82,41.01,60.19,111.27,119.77,124.03,128.91,129.36,130.95,134.46,135.46,148.04$, 155.79, 164.42 (oxadiazole C5), 164.84 (oxadiazole C2), $192.67(\mathrm{C}=\mathrm{O})$. LR-MS (m/z): calculated for $(\mathrm{M}+\mathrm{H})^{+}$: 383.142, found: 383 , calculated for (M-H): 381.142 , found: 381. Anal. Calcd. for $\mathrm{C}_{21} \mathrm{H}_{22} \mathrm{~N}_{2} \mathrm{O}_{3} \mathrm{~S} .1 / 2 \mathrm{H}_{2} \mathrm{O}: \mathrm{C}, 64.43$; H, 5.92; N, 7.16; S, 8.19. Found: C, 64.75; H, 5.93; N, 7.29; S, 9.09.

2-[5-\{[2-Methyl-5-(propan-2-yl)phenoxy]methyl\}-1,3,4-oxadiazol-2-yl)sulphanyl]-1-(4-chlorophenyl)ethan-1-one (3b): It was obtained as a white solid. HPLC $t_{\mathrm{R}}(\mathrm{min}): 24.69, \mathrm{M} . \mathrm{p}: 137-140{ }^{\circ} \mathrm{C}$, TLC R: 0.55 (S3), yield $46 \%$. IR $\mathrm{cm}^{-1}$ : 3100 and 3050 (Ar C-H str), 1671 (C=O), 1586 (C=N str), 1121 (C-O-C), 688 (C-S-C). ${ }^{1} \mathrm{H}$ NMR (300 MHz, DMSO$\left.\mathrm{d}_{6}\right)$ : $\delta: 1.17\left(\mathrm{~d}, 6 \mathrm{H}, \mathrm{J}=6.9 \mathrm{~Hz},-\mathrm{CH}\left(\mathrm{CH}_{3}\right)_{2}\right) ; 2.07\left(\mathrm{~s}, 3 \mathrm{H}, \mathrm{Ar}-\mathrm{CH}_{3}\right) ; 2.77-2.86\left(\mathrm{~m}, 1 \mathrm{H},-\mathrm{CH}\left(\mathrm{CH}_{3}\right)_{2}\right) ; 5.12$ (s, $2 \mathrm{H},-\mathrm{S}-$ $\left.\mathrm{CH}_{2-}\right) ; 5.37$ (s, 2H, -O-CH $\left.2^{-}\right) ; 6.77(\mathrm{dd}, 1 \mathrm{H}, \mathrm{J}=7.5 \mathrm{~Hz}, \mathrm{~J}=1.5 \mathrm{~Hz}, \mathrm{Ar}-\mathrm{H}) ; 6.96$ (s, 1H, Ar-H); 7.04 (d, $1 \mathrm{H}, J=7.5 \mathrm{~Hz}$, Ar-H); $7.66(\mathrm{dd}, 2 \mathrm{H}, \mathrm{J}=6.9 \mathrm{~Hz}, \mathrm{~J}=2.1 \mathrm{~Hz}, \mathrm{Ar}-\mathrm{H}) ; 8.06(\mathrm{dd}, 2 \mathrm{H}, \mathrm{J}=8.7 \mathrm{~Hz}, \mathrm{~J}=2.1 \mathrm{~Hz}, \mathrm{Ar}-\mathrm{H}) .{ }^{13 \mathrm{C}-\mathrm{NMR}}(150 \mathrm{MHz}$, DMSO-d 6 ): $\delta: 15.91,24.33,33.83,40.88,60.11,111.22,119.75,124.00,129.59,130.82,130.86,134.15,139.43,148.07$, 
155.77, 164.45 (oxadiazole C5), 164.77 (oxadiazole C2), 191.85 (C=O). LR-MS (m/z): calculated for $(\mathrm{M}+\mathrm{H})^{+}$: 417.103, found: 417, calculated for (M-H): 415.089, found: 415. Anal. Calcd. for $\mathrm{C}_{21} \mathrm{H}_{21} \mathrm{ClN}_{2} \mathrm{O}_{3} \mathrm{~S}: \mathrm{C}, 60.50 ; \mathrm{H}$, 5.08; N, 6.72; S, 7.69. Found: C, 60.60; H, 5.06; N, 6.66; S, 7.92.

2-[5-\{[2-Methyl-5-(propan-2-yl)phenoxy]methyl\}-1,3,4-oxadiazol-2-yl)sulphanyl]-1-(3,4-dichlorophenyl)ethan-1-one (3c): It was obtained as a yellow solid. HPLC $t_{R}(\mathrm{~min}): 33.12$, M.p: $111-113{ }^{\circ} \mathrm{C}$, TLC $\mathrm{R}_{\mathrm{f}}: 0.76(\mathrm{~S} 3)$, yield $37 \%$. IR $\mathrm{cm}^{-1}: 3086$ and 3070 (Ar C-H str), 1685 (C=O), 1581 (C=N str), 1170 (C-O-C), 703 (C-S-C). ${ }^{1} \mathrm{H}$ NMR (300 MHz, DMSO-d $\left._{6}\right): \delta: 1.17\left(\mathrm{~d}, 6 \mathrm{H}, \mathrm{J}=6.9 \mathrm{~Hz},-\mathrm{CH}\left(\mathrm{CH}_{3}\right)_{2}\right) ; 2.07\left(\mathrm{~s}, 3 \mathrm{H}, \mathrm{Ar}-\mathrm{CH}_{3}\right) ; 2.77-2.86\left(\mathrm{~m}, 1 \mathrm{H},-\mathrm{CH}\left(\mathrm{CH}_{3}\right)_{2}\right) ; 5.13(\mathrm{~s}$,

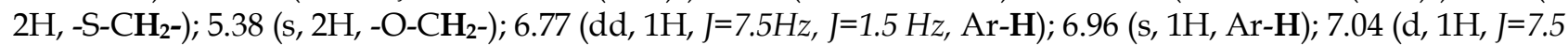
$\mathrm{Hz}$, Ar-H); 7.87 (d, 1H, J=8.7 Hz, Ar-H); 7.99 (dd, 1H, J=8.4 Hz, J=2.1 Hz, Ar-H); 8.27 (d, 1H, J=2.1 Hz, Ar-H). LR-MS (m/z): calculated for $(\mathrm{M}+\mathrm{H})^{+}: 451.064$, found: 451, calculated for $(\mathrm{M}-\mathrm{H}):: 449.050$, found: 449. Anal. Calcd. for $\mathrm{C}_{21} \mathrm{H}_{20} \mathrm{Cl}_{2} \mathrm{~N}_{2} \mathrm{O}_{3} \mathrm{~S}$ : C, 55.88; $\mathrm{H}, 4.47 ; \mathrm{N}, 6.21 ; \mathrm{S}$, 7.10. Found: $\mathrm{C}, 55.54 ; \mathrm{H}, 4.45 ; \mathrm{N}, 6.24 ; \mathrm{S}, 6.52$.

2-[5-\{[2-Methyl-5-(propan-2-yl)phenoxy]methyl\}-1,3,4-oxadiazol-2-yl)sulphanyl]-1-(4-(fluorophenyl)ethan-1-one (3d): It was obtained as white solid. HPLC $t_{R}(\mathrm{~min}): 18.44$, M.p: $101-103^{\circ} \mathrm{C}$, TLC $\mathrm{R}_{\mathrm{f}}: 0.60(\mathrm{~S} 3)$, yield $62 \%$. IR cm ${ }^{-1}: 1672$ $(\mathrm{C}=\mathrm{O}), 1589$ (C=N str), 1120 (C-O-C), 695 (C-S-C). ${ }^{1} \mathrm{H}$ NMR (300 MHz, DMSO-d 6 ): $\delta: 1.18$ (d, 6H, J=6.9 Hz, $\left.\mathrm{CH}\left(\mathrm{CH}_{3}\right)_{2}\right) ; 2.08\left(\mathrm{~s}, 3 \mathrm{H}, \mathrm{Ar}-\mathrm{CH}_{3}\right) ; 2.77-2.87\left(\mathrm{~m}, 1 \mathrm{H},-\mathrm{CH}\left(\mathrm{CH}_{3}\right)_{2}\right) ; 5.12\left(\mathrm{~s}, 2 \mathrm{H},-\mathrm{S}-\mathrm{CH}_{2}-\right) ; 5.37\left(\mathrm{~s}, 2 \mathrm{H},-\mathrm{O}-\mathrm{CH}_{2}-\right) ; 6.78$ (d, $1 \mathrm{H}, J=7.5 \mathrm{~Hz}$, Ar-H); 7.05 (d, 1H, J=7.8 Hz, Ar-H); 7.40 (t, 2H, J=7.8 Hz, Ar-H); 8.13 (dd, 2H, J=7.5 Hz, J=2.1 $\mathrm{Hz}$, Ar-H). LR-MS (m/z): calculated for $(\mathrm{M}+\mathrm{H})^{+}: 401.133$, found: 401. calculated for (M-H): : 399.118, found: 399. Anal. Calcd. for $\mathrm{C}_{21} \mathrm{H}_{21} \mathrm{FN}_{2} \mathrm{O}_{3} \mathrm{~S}$ : C, 62.98; $\mathrm{H}, 5.29 ; \mathrm{N}, 7.00 ; \mathrm{S}$, 8.01. Found: $\mathrm{C}, 62.16 ; \mathrm{H}, 5.10 ; \mathrm{N}, 6.86 ; \mathrm{S}, 7.83$.

2-[5-\{[2-Methyl-5-(propan-2-yl)phenoxy]methyl\}-1,3,4-oxadiazol-2-yl)sulphanyl]-1-(4-methoxyphenyl)ethan-1-one (3e): It was obtained as white solid. HPLC $\mathrm{t}_{\mathrm{R}}(\mathrm{min}): 17.88$, M.p: $86-88^{\circ} \mathrm{C}$, TLC $\mathrm{R}_{\mathrm{f}}: 0.61(\mathrm{~S} 3)$, yield $74 \%$. IR cm ${ }^{-1}$ : 3110 and 3050 (Ar C-H str), 1658 (C=O), 1595 (C=N str), 1201 (C-O-C), 692 (C-S-C). ${ }^{1} \mathrm{H}$ NMR (300 MHz, DMSO$\left.\mathrm{d}_{6}\right)$ : $\delta: 1.17\left(\mathrm{~d}, 6 \mathrm{H}, \mathrm{J}=6.9 \mathrm{~Hz}-\mathrm{CH}\left(\mathrm{CH}_{3}\right)_{2}\right) ; 2.07\left(\mathrm{~s}, 3 \mathrm{H}, \mathrm{Ar}-\mathrm{CH}_{3}\right) ; 2.77-2.87\left(\mathrm{~m}, 1 \mathrm{H},-\mathrm{CH}\left(\mathrm{CH}_{3}\right)_{2}\right) ; 3.34(\mathrm{~s}, 3 \mathrm{H},-$

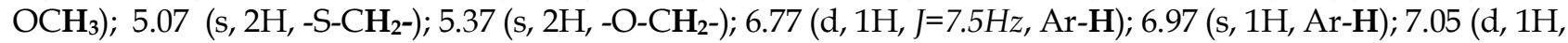
$J=7.8 \mathrm{~Hz}, \mathrm{Ar}-\mathrm{H}) ; 7.10$ (dd, 2H, J=8.7 Hz, J=2.1 Hz, Ar-H); 8.01 (dd, 2H, J=8.9 Hz, J=2.1 Hz, Ar-H). LR-MS (m/z): calculated for $(\mathrm{M}+\mathrm{H})^{+}: 413.153$, found: 413 , calculated for $(\mathrm{M}-\mathrm{H}):: 411.138$, found: 411 . Anal. Calcd. for $\mathrm{C}_{22} \mathrm{H}_{24} \mathrm{~N}_{2} \mathrm{O}_{4} \mathrm{~S}: \mathrm{C}, 64.06 ; \mathrm{H}, 5.86 ; \mathrm{N}, 6.79 ;$ S, 7.77. Found: $\mathrm{C}, 63.61 ; \mathrm{H}, 5.82 ; \mathrm{N}, 6.83 ; \mathrm{S}, 7.62$.

2-[5-\{[2-Methyl-5-(propan-2-yl)phenoxy]methyl\}-1,3,4-oxadiazol-2-yl)sulphanyl]-1-(4-bromine)ethan-1-one (3f): It was obtained as white solid. HPLC $t_{R}(\mathrm{~min}): 26.65$, M.p: $111-113^{\circ} \mathrm{C}$, TLC $\mathrm{R}_{\mathrm{f}}: 0.77(\mathrm{~S} 3)$, yield $37 \%$. IR cm ${ }^{-1}: 3097$ and 3014 (Ar C-H str), 1674 (C=O), 1581 (C=N str), 1128 (C-O-C), 707 (C-S-C). ${ }^{1}$ H NMR (300 MHz, DMSO-d ${ }_{6}$ ):

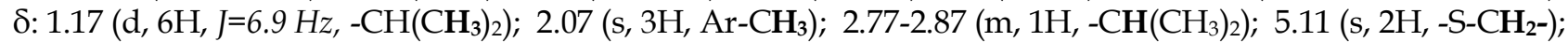
$5.37\left(\mathrm{~s}, 2 \mathrm{H},-\mathrm{O}-\mathrm{CH}_{2^{-}}\right) ; 6.78$ (d, 1H, J=7.5Hz, Ar-H); 6.96 (s, 1H, Ar-H); 7.05 (d, 1H, J=7.5 Hz, Ar-H); 7.80 (dd, 2H, $J=8.7 \mathrm{~Hz}, J=2.1 \mathrm{~Hz}, \mathrm{Ar}-\mathrm{H}) ; 7.97\left(\mathrm{dd}, 2 \mathrm{H}, J=8.7 \mathrm{~Hz}, J=2.1 \mathrm{~Hz}\right.$, Ar-H). LR-MS (m/z): calculated for $(\mathrm{M}+\mathrm{H})^{+}: 461.053$, found: 461, calculated for (M-H):: 459.038, found: 459. Anal. Calcd. for $\mathrm{C}_{21} \mathrm{H}_{21} \mathrm{BrN}_{2} \mathrm{O}_{3} \mathrm{~S} .1 / 2 \mathrm{H}_{2} \mathrm{O}: \mathrm{C}, 53.62 ; \mathrm{H}$, $4.71 ; \mathrm{N}, 5.96 ; \mathrm{S}, 6.82$. Found: $\mathrm{C}, 53.64 ; \mathrm{H}, 4.46 ; \mathrm{N}, 6.05 ; \mathrm{S}, 6.84$.

\subsection{Molecular modelling studies}

Compounds 3a-f were sketched and prepared according to "prepare ligands" protocol provided in BIOVIA Discovery Studio 4.5 [65]. Molecular docking was based on the crystal structures of COX-1 (PDB ID: 5WBE) [66], COX-2 (PDB ID: 5F19) [67] and mPGES-1 (PDB ID: 5K0I) [68]. Proteins were prepared using "prepare protein" protocol using BIOVIA, where missing loops or residues can be inserted, and hydrogen atoms were added. Docking study was performed using AutoDock4.2. All molecules were allowed to dock for twenty runs into their respective active site. Docking study was performed according to Lamarckian Genetic algorithm using 20 million energy evaluation.

\subsection{Biological assays}

\subsubsection{Cell culture studies}

Human cervical cancer cell line (HeLa), human breast cancer cell line (MCF-7), human prostate cancer cell line (PC-3), human lung cancer cell line (A549), human chronic myeloid leukemia cell line (K562) and nontumorigenic mouse embryonic fibroblast cell line (NIH3T3) were purchased from American Type Culture Collection (ATCC) (Manassas, VA, USA). Cells were cultured in Dulbecco's modified eagle medium (DMEM) (Gibco, Rockville, MD, USA) containing 10\% fetal bovine serum (FBS) (Gibco, Rockville, MD, USA) and maintained in a $37^{\circ} \mathrm{C}, 5 \% \mathrm{CO}_{2}$ incubator. Cell passage was conducted at $80-90 \%$ confluence. 


\subsubsection{Cell viability assay}

Cell viability was determined by the 3-(4,5-dimethylthiazol-2-yl)-2,5-diphenyltetrazolium bromide (MTT) assay. Briefly, the cells $\left(1 \times 10^{4}\right.$ cells/well $)$ were seeded onto 96-well plates and incubated overnight. Then, the cells were treated with $10 \mu \mathrm{M}$ of compounds for $48 \mathrm{~h}$. After the incubation period, MTT was added into each well to a final concentration of $0.5 \mathrm{mg} / \mathrm{mL}$ and incubated for $4 \mathrm{~h}$. The culture medium was then removed and $100 \mu \mathrm{L}$ of the SDS buffer was added to solubilize the purple formazan product. Absorbances at wavelengths of 570 and $630 \mathrm{~nm}$ were measured by a microplate reader (Biotek, Winooski, VT, USA).

\subsection{3. $m P G E S-1$ inhibition assays}

\section{Preparation of mPGES-1 enzymes}

The cloning of mPGES-1 enzyme and the preparation of protein followed the same protocols as described in our previous reports [69]. Briefly, FreeStyle Max Expression system was used to express wildtype human mPGES-1 enzymes. FreeStyle 293-F cells were cultured following manufacturer's manual in FreeStyle 293 expression medium on orbit rotate shaker in $8 \% \mathrm{CO}_{2}$ incubator at $37^{\circ} \mathrm{C}$. Cells were transfected with $1.5 \mu \mathrm{g} / \mathrm{mL}$ of mPGES-1/pcDNA3 construct using FreeStyle Max reagent at a cell density of $1 \times 10^{6}$ for two days. Transfected cells were collected, washed, and sonicated in TSES buffer $(15 \mathrm{mM} \mathrm{Tris-HCl,} \mathrm{pH} 8.0$ plus $0.25 \mathrm{M}$ sucrose, $0.1 \mathrm{mM}$ EDTA and $1 \mathrm{mM}$ DTT) on ice. The broken cells were first centrifuged at $12,500 \times$ $\mathrm{g}$ for $10 \mathrm{~min}$. The supernatant was further centrifuged at $105,000 \times \mathrm{g}$ for $1 \mathrm{~h}$ at $4{ }^{\circ} \mathrm{C}$. The residual pellet was washed and homogenized in PBS buffer. The crude microsomal mPGES-1 was aliquoted and stored at $-80{ }^{\circ} \mathrm{C}$ before use.

\section{Activity assay using a recombinant mPGES-1.}

The enzyme activity assay was performed using the same protocol as described in our previous reports [45, 70-72]. Briefly, the mPGES-1-catalyzed reaction was performed in $1.5 \mathrm{~mL}$ microcentrifuge tubes with reaction mixture of $0.2 \mathrm{Na}_{2} \mathrm{HPO}_{4} / \mathrm{NaH}_{2} \mathrm{PO}_{4}, \mathrm{pH} 7.2(10 \mu \mathrm{L}) ; 2.5 \mathrm{mM} \mathrm{GSH}(2.5 \mu \mathrm{L})$; diluted microsomal human mPGES-1 enzyme $(80 \mu \mathrm{g} / \mathrm{mL}, 1 \mu \mathrm{L})$; inhibitor in DMSO solution $(1 \mu \mathrm{L}) ; 0.31 \mathrm{mM}$ PGH2 in DMF $(5 \mu \mathrm{L})$ and distilled deionized water in a final volume of $100 \mu \mathrm{L}$. An inhibitor was incubated with the enzyme for 15 min at ambient temperature followed by the addition of substrate $\mathrm{PGH}_{2}$ (stored in dry ice). The enzymatic reaction was started immediately upon the addition of $\mathrm{PGH}_{2}$. After $1 \mathrm{~min}$ of reaction, solution $\left(40 \mathrm{mg} / \mathrm{mL} \mathrm{SnCl}_{2}\right.$ in absolute ethanol, $10 \mu \mathrm{L}$ ) was added to cease the reaction by converting excess $\mathrm{PGH}_{2}$ to $\mathrm{PGF}_{2 \alpha}$. The produced $\mathrm{PGE}_{2}$ from the enzymatic reaction was quantified by the $\mathrm{PGE}_{2}$ enzyme immunoassay as described earlier [73].

\subsubsection{COX-1/2 inhibition assays}

The inhibitory potential of all synthesized compounds on COX-1 and COX-2 enzymes were evaluated using a colorimetric COX Inhibitor Screening Kit (Cayman Chemical, Ann Arbor, MI, USA). The samples and control were dissolved in the DMSO and diluted with the reaction buffer to their final concentrations. DMSO served as a negative control for $100 \%$ initial activity. We have also tested for inhibitor interference by adding the inhibitor to a boiled enzyme sample as a control. The assay was conducted in duplicate.

^ This research was partly presented at the $2^{\text {nd }}$ International Gazi Pharma Symposium Series (GPSS 2017), 11-13 October 2017, Ankara, Turkey.

Acknowledgements: This study was supported by Marmara University Scientific Research Projects Commission under the grant no: SAG-C-DRP-081117-0616.

Author contributions: Concept - İ.K.; Design - İ.K., G.E.; Supervision - İ.K., C.-G.Z., K.Y., Ö.B.Ö.; Resources - İ.K., C.G.Z., K.Y., Ö.B.Ö.; Materials - İ.K., C.-G.Z., K.Y., Ö.B.Ö.; Data Collection and/or Processing - G.E., K.D., A.E., M.D., Ö.B.Ö.; Analysis and/or Interpretation - G.E., K.D., C.-G.Z., A.E., K.Y., M.D., Ö.B.Ö., İ.K.; Literature Search - G.E., C.G.Z., K.Y., Ö.B.Ö., İ.K. ; Writing - G.E., C.-G.Z., K.Y., Ö.B.Ö., İ.K.; Critical Reviews - G.E., K.D., C.-G.Z., A.E., K.Y., M.D., Ö.B.Ö., İ.K.

Conflict of interest statement: The authors declared no conflict of interest. 


\section{REFERENCES}

[1] Basile L, Álvarez S, Blanco A, Santagati A, Granata G, Di Pietro P, Guccione S, Muñoz-Fernández MA. Sulfonilamidothiopyrimidone and thiopyrimidone derivatives as selective COX-2 inhibitors: Synthesis, biological evaluation and docking studies. Eur J Med Chem. 2012; 57(0): 149-161. [CrossRef]

[2] Charlier C, Michaux C. Dual inhibition of cyclooxygenase-2 (COX-2) and 5-lipoxygenase (5-LOX) as a new strategy to provide safer non-steroidal anti-inflammatory drugs. Eur J Med Chem. 2003; 38(7-8): 645-659. [CrossRef]

[3] Dannhardt G, Kiefer W. Cyclooxygenase Inhıbitors-Current Status and Future Prospects. Eur J Med Chem. 2001; 36: 109-126. [CrossRef]

[4] Samuelsson B, Morgenstern R, Jakobsson PJ. Membrane prostaglandin E synthase-1: A novel therapeutic target. Pharmacol Rev. 2007; 59: 207-224. [CrossRef]

[5] Akasaka H, So SP, Ruan KH. Relationship of the topological distances and activities between mPGES-1 and COX-2 versus COX-1: implications of the diffirent post- translational endoplasmic reticulum organizations of COX-1 and COX-2. Biochemistry. 2015; 54: 3707-3715. [CrossRef]

[6] Whittle BJR. Gastrointestinal effects of nonsteroidal anti-inflammatory drugs. Fund Clin Pharmacol. 2003; 17(3): 301313. [CrossRef]

[7] Laine L. The gastrointestinal effects of nonselective NSAIDs and COX-2 selective inhibitors. Semin Arthritis Rheum. 2002; 32(3): 25-32. [CrossRef]

[8] Chang HH, Meuillet EJ. Identification and development of mPGES-1 inhibitors: where are we at? Future Med Chem. 2011; 3(15): 1909-1934. [CrossRef]

[9] Bülbül B, Küçükgüzel I. Microsamal prostaglandin E2 synthase-1 as a new macromolecular drug target in the prevention of inflammation and cancer. Anti-Cancer Agents Med Chem. 2019; 19(10): 1205-1222. [CrossRef]

[10] Kadi AA, El-Brollosy NR, Al-Deeb OA, Habib EE, Ibrahim TM, El-Emam AA. Synthesis,antimicrobial and a antiinflammatory activities of novel 2-(1-adamantyl)-5-substituted-1,3,4-oxadiazoles and 2-(1-adamantylamino)-5substitued-1,3,4-thiadiazoles. Eur J Med Chem. 2007; 42: 235-242. [CrossRef]

[11] Ahsan MJ, Samy JG, Khalilullah MS, Nomani MS, Saraswat P, Gaur R, Singh A. Molecular properties prediction and synthesis of novel 1,3,4-oxadiazole analogues as potent antimicrobial and antitubercular agents. Bioorg Med Chem Lett. 2011; 21: 7246-7250. [CrossRef]

[12] Pinna GA, Murineddu G, Murruzzu C, Zuco V, Zunino F, Cappelletti G, Artali R, Cignarella G, Solano L, Villa S. Synthesis, modelling and antimitotic porperties of tricyclic systems characterized by a 2-(5-phenyl-1-H-pyyrol-3-yl)1,3,4-oxadiazole moeity. ChemMedChem. 2009; 4: 998-1009. [CrossRef]

[13] Zhang XM, Qui M, Sun J, Zhang YB, Yang YS, Wang XL, Zhu HL. Synthesis, biological evaluation and molecular docking studies of 1,3,4-oxadiazole derivatives possessing 1,4-benzodioxan moeity as potential anticancer agents. Bioorg Med Chem. 2011; 19: 6518-6524. [CrossRef]

[14] Du QR, Li DD, Pi YZ, Li JR, Sun J, Fang F, Zhong WQ, Gong HB, Zhu HL. Novel 1,3,4-oxadiazole thioether derivatives targeting thymidylate synthase as dual anticancer/antimicrobial agents. Bioorg Med Chem. 2013: 21; $2286-2297$. [CrossRef]

[15] Bajaj S, Roy PP, Singh J. Synthesis, thmynidine phosphorylase inhibitory and computational study of novel 1,3,4oxadizole-2-thione derivatives as a potential anticancer agents. Comput Biol Chem. 2018; 74: 151-160. [CrossRef]

[16] Kulabaş N, Tatar E, Özakpınar ÖB, Özsavcı D, Pannecouque C, De Clercq E, Küçükgüzel İ. Synthesis and antiproliferative evaluation of novel 2-(4H-1,2,4-triazole-3-ylthio)acetamide derivatives as inducers of apoptosis in cancer cells. Eur J Med Chem. 2016; 121: 58-70. [CrossRef]

[17] Gahani U, Ullah N. New potent inhibitors of tyrosinase: Novel clues to binding of 1,3,4-thiadiazole-2(3H)-thiones, 1,3,4-oxadiazole-2(3H)-thiones, 4-amino-1,2,4-triazole-5(4H)-thiones, and substituted hydrazides to the dicopper active site. Bioorg Med Chem. 2010; 18(11): 4042-4048. [CrossRef]

[18] Zhang LR, Liu ZJ, Zhang H, Sun J, Luo Y, Zhao TT, Gong HB, Zhu HL. Synthesis, biological evaluation and molecular docking studies of novel 2-(1,3,4-oxadiazol-2-ylthio)-1-phenylethanone derivatives. Bioorg Med Chem. 2012; 20: 3615-3621. [CrossRef]

[19] Zhang S, Luo Y, He LQ, Liu ZJ, Jiang AQ, Yang YH, Zhu HL. Synthesis, biological evaluation and molecular docking studies of novel 1,3,4-oxadiazole derivatives possesing benzotriazole moiety as FAK inhibitors with anticancer activity. Bioorg Med Chem. 2013; 21: 3723-3729. [CrossRef]

[20] Yurttaş L, Bülbül EF, Tekinkoca S, Demirayak Ş. Antimicrobial activity evaluation of new 1,3,4-oxadiazole derivatives. Acta Pharm Sci. 2017; 55(2): 45-54. [CrossRef] 
[21] He S, Li C, Liu Y, Lai L. Discovery of highly potent microsomal prostaglandin E2 synthase-1 inhibitors using the active conformation structural model and virtual screen. J Med Chem. 2013; 56: 3296-3309. [CrossRef]

[22] Abd-Ellah SH, Abdel-Aziz M, Shoman ME, Beshr EAM, Kaoud TS, Ahmed ASFF. New 1,3,4-oxadiazole/oxime hybrids: Design, synthesis, anti-inflammatory, COX inhibitory and ulcerogenic liability. Bioorg Chem. 2017; 74: 1529. [CrossRef]

[23] Wu W, Chen Q, Tai A, Jiang G, Ouyang G. Synthesis and antiviral activity of 2-substitutedmethylthio-5-(4-amino-2methylpyrimidin-5-yl)-1,3,4-oxadiazole derivatives. Bioorg Med Chem Lett. 2015; 25: 2243-2246. [CrossRef]

[24] Kordali S, Cakir A, Ozer H, Ckamakc1 R, Kesdek M, Mete E. Antifungal, phytotoxic and insecticidal proporteis of essentiaol oil isolated Turkish Orifanum acutidens and its three components carvacrol, thymol and p-cymene. Biosource Tech. 2008; 99: 8788-8795. [CrossRef]

[25] Guarda A, Rubilar JF, Miltz J, Galotto MJ. The antimicrobial activity of microencapsulated thymol and carvacrol. J Food Microbiol. 2011; 146: 144-150. [CrossRef]

[26] Ghomi JS, Ebrahimabadi AH, Bidgoli ZD, Batooli H. GC/MS analysis and in vitro antioxidant activity of essantial oil and methanol extracts of Thymus caramicus jalas and its main constituent carvacrol. Food Chem. 2009; 115: 15241528. [CrossRef]

[27] Yin QH, Yan FX, Zu XY, Wu YH, Wu XP, Liao MC, Deng SW, Yin LI, Zhuang YZ. Anti-proliferative and pro-apoptotic effect of carvacrol on human hepatocellular carcinoma cell line HepG-2. Cytotechnology. 2012; 64: 43-51. [CrossRef]

[28] Fan K, Xiaolei L, Cao Y, Qi H, Li L, Zhang Q, Sun H. Carvacrol inhibits proliferation and induces apoptosis in human colon cancer cells. Anti-Cancer Drugs. 2015; 26(8): 813-823. [CrossRef]

[29] Günes-Bayır A, Kızıltan HS, Kocyigit A, Güler EM, Karatas E, Toprak A. Effects of natural phenolic compound carvacrol on the human gastric adenocarcinoma (AGS) cells in vitro. Anti-Cancer Drugs. 2017; 28: 522-530. [CrossRef]

[30] Wagner H, Wierer M, Bauer R. In vitro inhibition of prostaglandin biosynthesis by essential oils and phenolic compounds. Planta Med. 1986; 52: 184-187.

[31] Landa P, Kokoska L, Pribylova M, Vanek T, Marsik P. In vitro anti-inflammatory activity of carvacrol: Inhibitory effect on COX-2 catalyzed prostaglandin E2 biosynthesis. Arch Pharm Res 2009; 32: 75-78. [CrossRef]

[32] Lima MDS, Quintans-Junior L, Santana WAD, Kaneto CM, Soaers MBP, Villareal CF. Anti-inflammatory effects of carvacrol: Evidence for a key role of interleukin-10. Eur J Pharm. 2013; 699: 112-117. [CrossRef]

[33] Riendeau D, Aspiotis R, Ethier D, Gareau Y, Grimm EL, Guay J, Guiral S, Juteau H, Mancini JA, Methot N, Rubin J, Friesen RW. Inhibitors of the inducible microsomal prostaglandin E2 synthase (mPGES-1) derived from MK-886. Bioorg Med Chem Lett. 2005; 15: 3352-3355. [CrossRef]

[34] Cote B, Boulet L, Brideau C, Claveau D, Ethier D, Frenette R, Gagnon M, Giroux A, Guay J, Guiral S, Mancini J, Martins E, Masse F, Methot N, Riendeau D, Rubin J, Xu D, Yu H, Ducharme Y, Friesen RW. Substituted phenanthrene imidazoles as potent, selective, and orally active mPGES-1 inhibitors. Bioorg Med Chem Lett. 2007; 17: 6816-6820. [CrossRef]

[35] Wu YC, Su LJ, Wang HW, Lin CFJ, Hsu WH, Chou TY, Huang CFY, Lu CL, Hsueh CT. Co-Overexpression of Cyclooxygenase- 2 and microsomal prostaglandin E synthase-1 adversely affects the prospective survival in nonsmall cell lung cancer. J Thorac Oncol. 2010; 5(8): 1167-1174. [CrossRef]

[36] Chiasson JF, Boulet L, Brideau C, Chau A, Claveau D, Cote B, Ethier D, Giroux A, Guay J, Guiral S, Mancini J, Masse F, Methot N, Riendeau D, Roy P, Rubin J, Xu D, Yu H, Ducharme Y, Friesen RW. Trisubstituted ureas as potent and selective mPGES-1 inhibitors. Bioorg Med Chem Lett. 2011; 21: 1488-1492. [CrossRef]

[37] Shiro T, Takahashi H, Kakiguchi K, Inoue Y, Masuda K, Nagata H, Tobe M. Synthesis and SAR study of imidazoquinolines as a novel structural class of microsomal prostaglandin E2 synthase-1 inhibitors. Bioorg Med Chem Lett. 2012; 22: 285-288. [CrossRef]

[38] Shiro T, Kakiguchi K, Takahashi H, Nagata H, Tobe M. Synthesis and biological evaluation of substituted imidazoquinoline derivatives as mPGES-1 inhibitors. Bioorg. Med Chem. 2013; 21: 2068-2078. [CrossRef]

[39] Shiro T, Kakiguchi K, Takahashi H, Nagata H, Tobe M. 7-Phenyl-imidazoquinolin-4(5H)-one derivatives as selective and orally available mPGES-1 inhibitors. Bioorg Med Chem. 2013; 21: 2868-2878. [CrossRef]

[40] Lauro G, Tortorella P, Bertamino A, Ostacolo C, Koeerle A, Fischer K, Brun I, Terracciano S, Monterrey IMG, Tauro M, Loiodice F, Novellino E, Riccio R, Werz O, Campiglia P, Bifulco G. Structure-based design of microsomal prostaglandin E2 synthase (mPGES-1) inhibitors using a virtual fragment growing optimization scheme. ChemMedChem. 2016; 11: 612-619. [CrossRef] 
[41] Larsson K, Jakobbson PJ. Inhibition of microsamal prostaglandin E synthase-1 as targeted therapy in cancer treatment. Prostg Oth Lip M. 2015; 120: 161-165. [CrossRef]

[42] Koeberle A, Laufer SA, Werz O. Design and development of microsomal prostaglandin E2 synthase-1 inhibitors: challenges and future directions. J Med Chem. 2016; 59: 5970-5986. [CrossRef]

[43] Jin Y, Smith CL, Hu L, Campanale KM, Stoltz R Huffman Jr LG, McNearney TA, Yang XY, Ackermann BL, Dean R, Regev A, Landschulz W. Pharmacodynamic comparison of LY3023703, a novel microsomal prostaglandine synthase 1 inhibitor, with celecoxib. Clin Pharmacol Ther. 2016; 99; 274-284. [CrossRef]

[44] Sant S, Tandon M, Menon V, Gudi G, Kattige V, Joshi NK, Korukonda K, Dolberg OL. GRC 27864, novel, microsomal prostaglandin E synthase-1 enzyme inhibitor: phase 1 study to evaluate safety, PK and biomarkers in healthy, adult subjects. Osteoarthr Cartilage. 2018; 26(1): 351-352. [CrossRef]

[45] Ding K, Zhou Z, Hou S, Yuan Y, Zhou S, Zheng J, Chen C, Loftin C, Zheng F, Zhan CG. Structure-based discovery of mPGES-1 inhibitors suitable for preclinical testing in wild-type mice as a new generation of anti-inflammatory drugs. Sci Rep. 2018; 8: 5205. [CrossRef]

[46] Waltenberger B, Wiechmann K, Bauer J, Markt P, Noha SM, Wolber G, Rollinger JM, Werz O, Schuster D, Stuppner H. Pharmacophore modelling and virtual screening for novel acidic inhibitors of microsomal prostglandin E2 synthase-1 (mPGES-1). J Med Chem. 2011; 54: 3163-3174. [CrossRef]

[47] Bergqvist F, Ossiåpva E, Weway K, Idprg H, Checa A, Englund K, Englund P, Khoonsari PE, Kultima K, Wheelock CE, Larsson K, Korotkova M, Jakobsson PJ. Inhibition of mPGES-1 or COX-2 results in different proteomic and lipidomic profiles in A549 lung cancer cells. Front Pharmocol. 2019; 10: 636. [CrossRef]

[48] Gür ZT, Çalışkan B, Garscha U, Olgaç A, Schubert US, Gerstmeier J, Werz O, Banoğlu E. Identificationof multi-target inhibitors of leukotriene and prostaglandin E2 biosynthesis by structural tuning og the FLAP inhibitor BRP-7. Eur J Med Chem. 2018; 150: 876-899. [CrossRef]

[49] Bagul SD, Rajput JD, Tadavi SK, Bendre RS. Design, synthesis and biological activities of novel 5-isopropyl-2 methylphenolhyrazide-based sulfonamide derivatives. Res Chem Intermed. 2016; 43(4): 2241-2252. [CrossRef]

[50] Lacasse G, Muchowski JM. Five-Membered Heterocylic Thions. Part II. Oxadiazole-2-thione. Can J Chem. 1972; 50: 3082-3083.

[51] Öztürk S, Akkurt M, Cansız A, Çetin A, Şekerci M, Heinemann FW. 5-(Furan-2-yl)-1,3,4-oxadiazole-2(3H)-thione. Acta Crystallogr B. 2004; E60: o322-o323. [CrossRef]

[52] Horning DE, Muchowski JM. Five-membered heterocyclic thiones. Part I. 1,3,4-oxadiazole-2-thione. Canadian J Chem. 1972; 50: 3079.

[53] Tomi IHR, Al-Qaisi AHJ, Al-Qaisi ZHJ. Synthesis, characterization and effect of bis 1,3,4-oxadiazole containing glycine moeity on the activity of some trasnferase enzymes. J King Saud Univ Sci. 2011; 23(3): 23-33. [CrossRef]

[54] Gürsoy A, Demirayak Ş, Cesur Z, Reisch J, Ötük G. Synthesis of some new hyrdazide-hydrazones, thiosemicarbazides, thiadiazoles, triazoles and their derivatives as possible antimicrobials. Pharmazie. 1990; 21(42): 246-250. [CrossRef]

[55] Hamza A, Zhao X, Tong M, Tong M, Tai HH, Zhan CG. Novel human mPGES-1 inhibitors identifed through structure-based virtual screening. Bioorg Med Chem. 2011; 19(20); 6077-6086. [CrossRef]

[56] Dhanjal JK, Sreenidhi AK, Bafna K, Katiyar SP, Goyal S, Grover A, Sundar D. Computational structure-based de novo design of hypothetical inhibitors against the anti-inflammatory target COX-2. PloS ONE. 2015; 10(8), e0134691. [CrossRef]

[57] Morris GM, Ruth H, Lindstorm W, Sanner MF, Belew RK, Goodsell DS, Olson AJ. Software news and updates AutoDock4 and AutoDockTools4: Automated docking with selective receptor flexibility. J Comp Chem. 2009; 30(16): 2785-2791. [CrossRef]

[58] SwissADME, http:/ /www.swissadme.ch/ (accessed on 29 Jan 2020).

[59] Zhao YH, Abraham MH, Le J, Hersey A, Luscombe CN, Beck G, Sherbone B, Cooper I. Rate'limited steps of human oral absorption and QSAR studies. Pharm Res. 2002; 19(10): 1446-1457. [CrossRef]

[60] Fromm MF. P-glycoprotein: A defense mechanism limiting oral bioavailability and CNS accumulation of drugs. Int J Clin Pharmacol Ther 2000; 38: 69-74. [CrossRef]

[61] Kaplan YC, Gelal A. The role of p-glycoprotein in pharmacokinetics and toxicokinetic. Turkiye Klinikleri J Surg Med Sci. 2006; 2(46): 33-38.

[62] Daina A, Zoete V. A BOILED-Egg to predict gastroinstestinal absorption and brain penetration of small molecules. ChemMedChem. 2016; 11(11): 1117-1121. [CrossRef] 
[63] ACD Labs, https://www.acdlabs.com/index.php (accessed on 29 Jan 2020).

[64] Manjunatha K, Poojary B, Lobo PL, Fernandes J, Kumari NS. Synthesis and biological evaluation of some 1,3,4oxadiazole derivatives. Eur J Med Chem. 2010; 45: 5225-5233. [CrossRef]

[65] Dassault Systèmes BIOVIA Discovery Studio 2017 R2: A comprehensive predictive science application for the Life Sciences. San Diego, CA, USA. (2017).

[66] Cingolani G, Panella A, Perrone MG, Vitale P, Di Mauro G, Fortuna CG, Armen RE, Ferorelli S, Smith WL, Scilimati A. Structural basis for selective inhibition of cyclooxygenase-1 (COX-1) by diarylisoxazoles mofezolac and 3-(5chlorofuran-2-yl)-5-methyl-4-phenylisoxazole. Eur J Med Chem. 2017; 138: 661-668. [CrossRef]

[67] Lucido MJ, Orlando BJ, Vecchio AJ, Malkowski MG. Crystal structure of aspirin-acetylated human Cyclooxygenase2: Insight into the formation of products with reversed stereochemistry. Biochemistry. 2016; 55(8): $1226-1238$. [CrossRef]

[68] Kuklish SL, Antonysamy S, Bhattachar SN, Chandrasekhar S, Fisher MJ, Fretland AJ, Gooding K, Harvey A, Hugnes NE, Luz JG, Manninen PR, McGee JE, Navarro A, Norman BH, Prtridge KM, Quimby SJ, Schiffler MA, Sloan AV, Warshawsky AM, York JS, Yu XP. Characterization of 3,3-dimethyl substituted N-aryl piperidines as potent microsomal prostaglandin E synthase-1 inhibitors. Bioorg Med Chem Lett. 2016; 26(19): 4824-4828. [CrossRef]

[69] Hamza A, Tong M, Abdulhameed MDM, Liu J, Goren AC, Tai HH, Zhan CG. Understanding microscopic binding of human microsomal prostaglandin E synthase-1 (mPGES-1) trimer with substrate $\mathrm{PGH}_{2}$ and cofactor GSH: Insights from computational alanine scanning and site-directed mutagenesis. J Phys Chem B. 2010; 114: 5605-5616. [CrossRef]

[70] Ding K, Zhou Z, Zhou S, Yuan X, Kim K, Zhang T, Zheng X, Zheng F, Zhan CG. Design, synthesis and discovery of 5-((1,3-diphenyl-1H-pyrazol-4-yl)methylene)pyrimidine-2,4,6(1H,3H,5H)-triones and related derivatives as novel inhibitors of mPGES-1. Bioorg Med Chem Lett. 2018; 27: 858-862. [CrossRef]

[71] Hamza A, Zhao X, Tong M, Tai HH, Zhan CG. Bioorg Med Chem. Novel human mPGES-1 inhibitors identified through structure-based virtual screening. Bioorg Med Chem. 2011; 19: 6077-6086. [CrossRef]

[72] Zhou Z, Yuan Y, Zhou S, Ding K, Zheng F, Zhan CG. Selective inhibitors of human mPGES-1 from structure-based computational screening. Bioorg Med Chem Lett. 2017; 27: 3739-3743. [CrossRef]

[73] Harding L, Wang Z, Tai HH. Stimulation of prostaglandin E2 synthesis by interleukin-1 $\beta$ is amplified by interferons but inhibited by interleukin-4 in human amnion-derived WISH cells. Biochim Biophys Acta. 1996; 1310: 48-52. [CrossRef] 